\title{
An Overview of the Production of Oxygenated Fuel Additives by Glycerol Etherification, Either with Isobutene or tert-Butyl Alcohol, over Heterogeneous Catalysts
}

\author{
Rafael Estevez *, Laura Aguado-Deblas, Diego Luna® and Felipa M. Bautista * \\ Departamento de Química Orgánica, Ed. Marie Curie, Campus de Rabanales, Instituto Universitario de \\ Nanoquímica (IUNAN), Universidad de Córdoba, 14071 Córdoba, Spain; aguadolaura8@gmail.com (L.A.-D.); \\ qo1lumad@uco.es (D.L.) \\ * Correspondence: q72estor@uco.es (R.E.); qo1baruf@uco.es (F.M.B.); Tel.: +34-957-212-065 (F.M.B.)
}

Received: 21 May 2019; Accepted: 18 June 2019; Published: 19 June 2019

check for updates

\begin{abstract}
Biodiesel production has considerably increased in recent decades, generating a surplus of crude glycerol, which is the main drawback for the economy of the process. To overcome this, many scientists have directed their efforts to transform glycerol, which has great potential as a platform molecule, into value-added products. A promising option is the preparation of oxygenate additives for fuel, in particular those obtained by the etherification reaction of glycerol with alcohols or olefins, mainly using heterogeneous catalysis. This review collects up-to-date research findings in the etherification of glycerol, either with isobutene (IB) or tert-Butyl alcohol (TBA), highlighting the best catalytic performances reported. Furthermore, the experimental sets employed for these reactions have been included in the present manuscript. Likewise, the characteristics of the glycerol ethers-(bio)fuel blends as well as their performances (e.g., quality of emissions, technical advantages or disadvantages, etc.) have been also compiled and discussed.
\end{abstract}

Keywords: glycerol; heterogeneous catalysis; etherification; isobutene; tert-Butyl alcohol; oxygenated fuel additives

\section{Introduction}

Nowadays, fossil fuels are the main energetic source in the world. Furthermore, as industrialization and modernization increase day by day, it is expected that the demand of these energetic resources will continue to increase. In fact, the data published by the Organization of the Petroleum Exporting Countries (OPEC), in January of 2017, stated that the world oil supply was $95.7 \mathrm{mbd}$, whereas in 2015 the average world oil supply was $92.7 \mathrm{mbd}$. The unavoidable decrease in the world crude oil reserves, together with the higher demand, will cause a progressive increase in price. Thus, the spot price of the OPEC basket (65.33 US $\$ / b$, according to the Market Indicators in November 2018) has supposed an increase of 33\% in respect to the price established in November of 2016 [1]. Very recently, the U.S. Energy Information Administration (EIA) forecast the world crude oil prices to rise gradually, averaging $\$ 65$ per barrel in 2020, whereas the world benchmark Brent crude oil will average $\$ 61$ per barrel in 2019. In addition to those facts, some experts have also predicted that the current oil supply may be completely depleted by the year 2050 [2].

In addition to the economic aspect, environmentally friendly alternatives which are able to palliate and/or substitute the use of fossil fuels as the main energetic source must be taken into account. With this in mind, the EU stated that, in 2010, traffic fuels must contain at least $5.75 \%$ of renewable bio-components, increasing this percentage up to $20 \%$ in 2020 and 30\% in 2030 [3]. Besides, the United 
States Department of Energy (DOE) has set among its objectives the replacement of 30\% of fossil fuels with biofuels, as well as $25 \%$ of the industrial organic chemicals by biomass-derived chemical compound by 2025 [4].

Renewable energy sources such as solar, hydroelectric, wind, geothermal, and biomass can be considered as viable alternatives to conventional crude oil [5]. Among these alternatives, biomass has emerged as the most viable option to substitute fossil fuels for different reasons (e.g., it is a plentiful source of renewable carbon for the production of biofuels and fine chemicals) [6-9]. Furthermore, the energy production from biomass generates a lower amount of greenhouse gases than fossil fuels [10]. Therefore, the objective is the implementation of a biorefinery in which, as occurs in current refineries, biofuels, high-value chemicals, and bio-based products can be obtained from biomass (Figure 1).

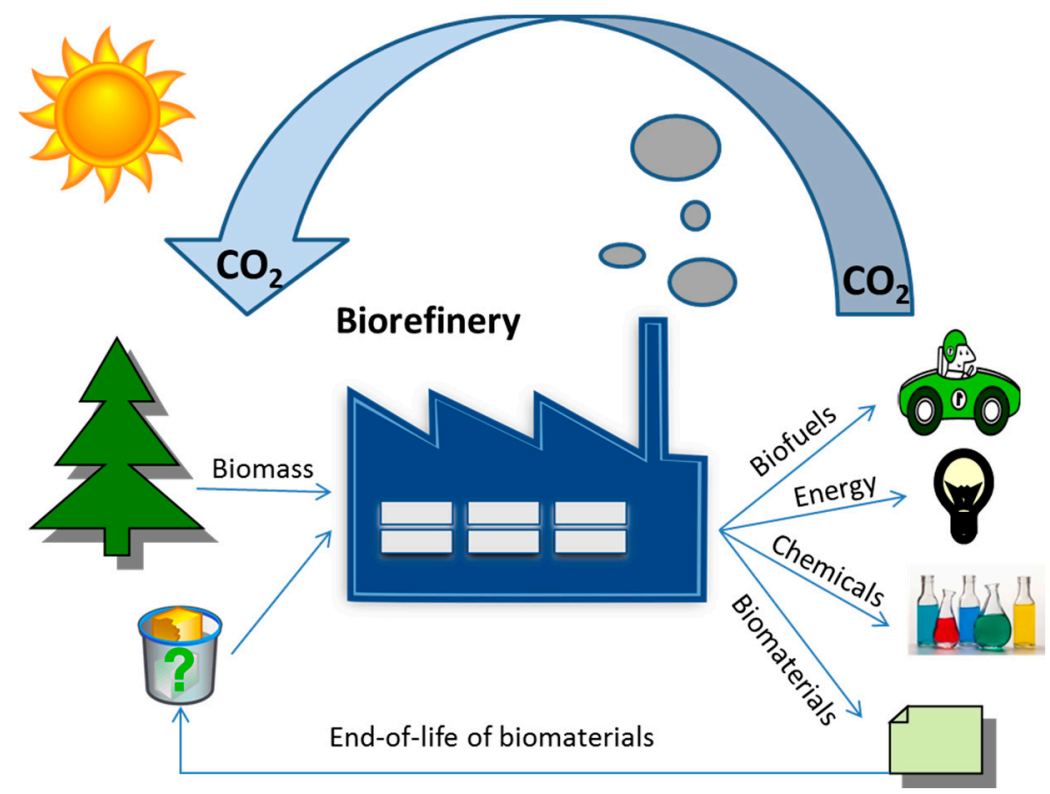

Figure 1. Diagram of a sustainable biorefinery process. Adapted from Ragauskas et al. [11] and Mohan et al. [12].

In the last two decades, the production of biofuels from biomass, especially to produce biodiesel, has received much attention. In fact, according to data reported by the EIA, the production of biodiesel in the United States increased in 2017 and 2018, Figure 2, despite the expiry of fiscal aids to the sector at the end of 2016 [13].

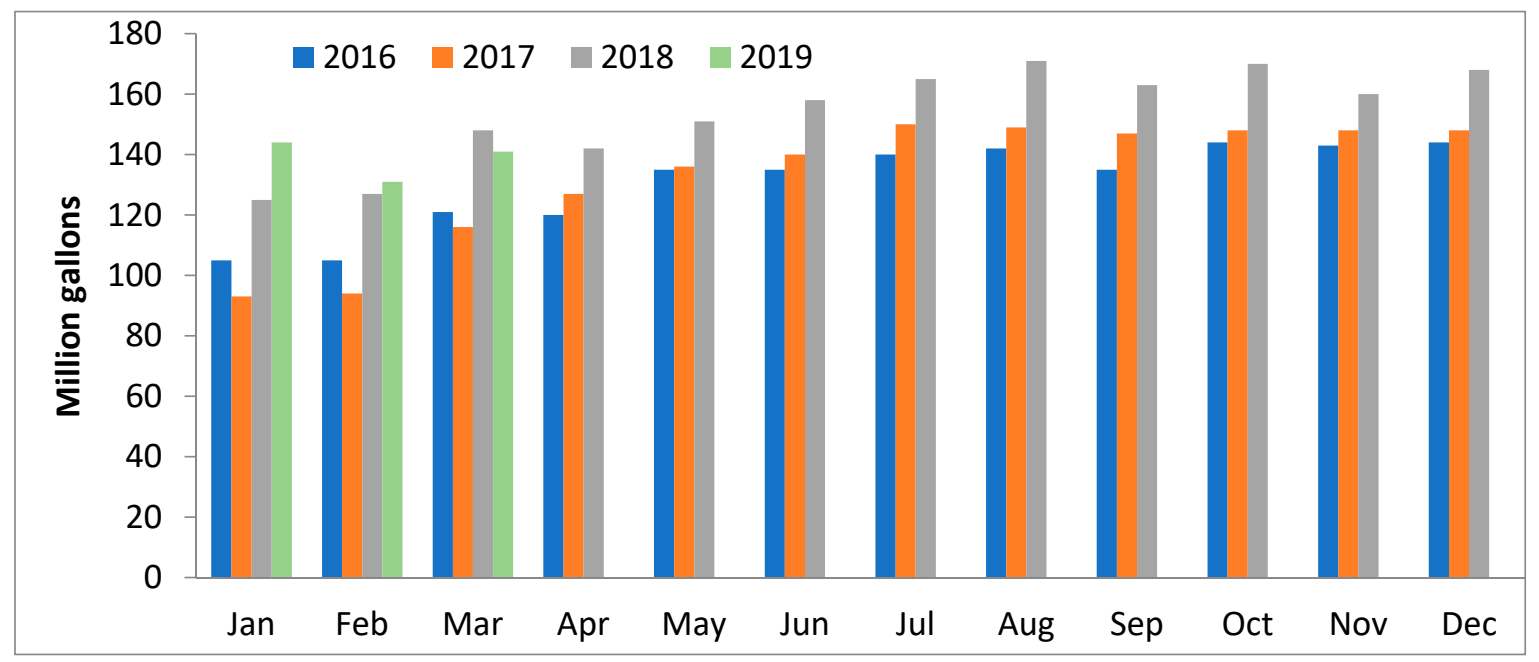

Figure 2. U.S. monthly biodiesel production 2016-2019 [13]. 
In fact, the increase in the production of biodiesel in the United States was decisive for the global biodiesel production (36.6 billion liters), around 1\% higher than the previous year (34 billion liters) [14].

The skyrocketing production of biodiesel in recent decades is related to the inherent advantages that this biofuel exhibits to substitute fossil fuels, such as the low toxicity that it exhibits and its biodegradable, renewable, and biocompatible character. Furthermore, biodiesel can be easily integrated into the logistics of the global transportation system $[15,16]$ and fits into existing engines with little or no modifications needed [17]. Biodiesel is obtained as a mixture of ethyl and methyl esters of fatty acids (FAEE or FAME), from vegetable oils or animal fats, through a transesterification reaction with a mono-alcohol, usually methanol, in the presence of an alkali homogeneous catalyst (Scheme 1). However, many researches are still being carried out, backed up by government policies, fiscal incentives, and emission laws, which aim to overcome different problems related to biodiesel production (e.g., economical and ethical aspects, as well as the valorization of the by-products generated). Hence, new catalytic systems and different feedstocks for biodiesel production are still being investigated [18-20].

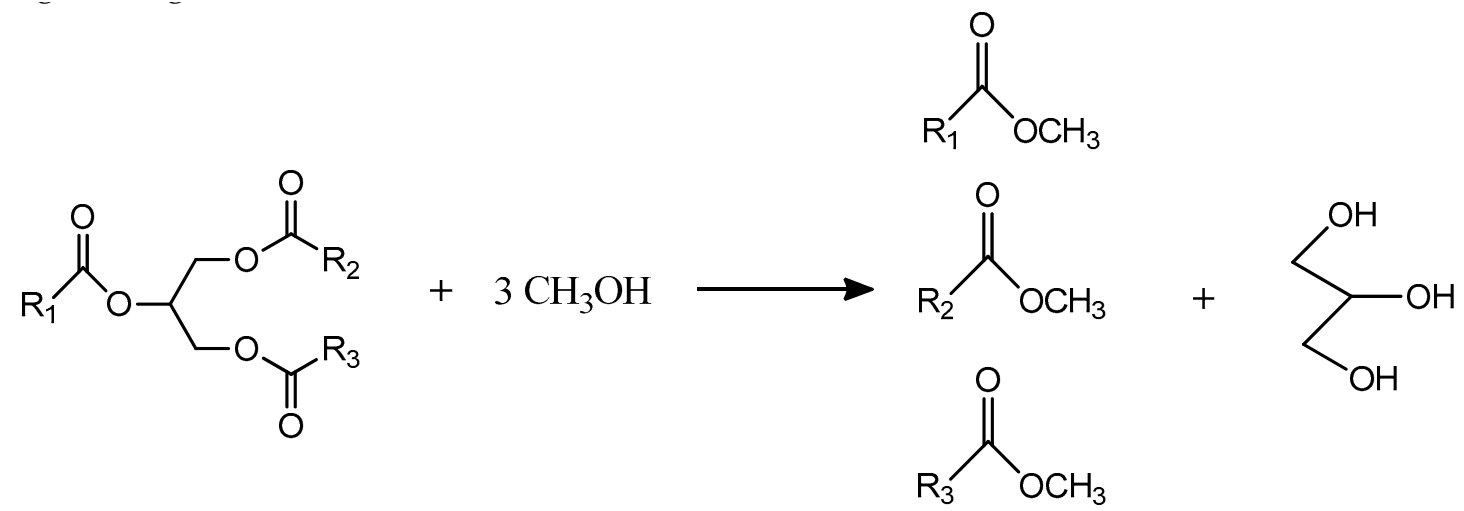

Scheme 1. Biodiesel production by transesterification of triglycerides with methanol.

Taking into account the biofuel synthesis and the available technology, the conventional biodiesel production, described by the standard EN 14214, presents the glycerol generated as a byproduct as the main drawback, which is $10 \%$ by weight of the biodiesel produced, constituting the major bottleneck in the production process [21]. Therefore, it is mandatory to obtain new and economically feasible ways of transforming glycerol, in order to enhance the sustainability of the biodiesel industries by increasing the crude glycerol value.

As it is well-known, glycerol exhibits a great versatility for being employed in different fields, such as cosmetic, food, pharmaceutical, and polymer industries and so on [2,22]. All these industries require glycerol with a high purity. However, crude glycerol from the biodiesel industry is a mixture of glycerol $(\sim 80 \%)$, water $(\sim 10 \%), \mathrm{NaCl}(\sim 10 \%)$, and methanol $(<1 \%)$. Hence, a purification step of the crude glycerol phase to obtain a pure $88 \%-90 \%$ glycerol is mandatory. In addition to this, a further purification step is necessary to produce the pharmaceutical-grade glycerol meeting EU Pharmacopeia standard 99.5, thus making the process more expensive [23].

With this in mind, it is easy to understand the efforts carried out by the scientific community in order to obtain value-added products from glycerol, which can be introduced into the concept of biorefinery. In this sense, several recent reviews collected different approaches to transform glycerol into value-added products $[2,21,24,25]$. A summary of the applications of these glycerol derivatives is shown in Figure 3. In general, these products are obtained mainly by reactions in the presence of heterogeneous catalysts (e.g. hydrogenolysis, dehydration, esterification, etherification, acetalization, and so on) [26-28], making glycerol one of the most important platform molecules currently employed.

Among all the options to transform glycerol into value-added chemicals, the production of oxygenated fuel additives has gained greater attention in recent years [10,27-30]. By definition, a fuel additive is a chemical substance that can be blended with fuel (diesel, gasoline, and/or biodiesel) and it 
is capable of enhancing the engine performance by improving fuel properties, cleaning engine parts, reducing the consumption ratio, and/or decreasing greenhouse gas emissions $[10,31]$.

Oxygenated fuel additives increase the octane rating and the combustion quality in the engine, since they reduce the particulate matter emission and the carbon monoxide production. The oxygenated fuel additives obtained from glycerol can be classified in three groups: Those obtained by glycerol acetylation, usually called acetin; the glycerol ethers; and the glycerol formal and ketals, obtained by the reaction of glycerol either with formaldehyde or acetone. These additives are considered as a good option to replace those petroleum-based additives, such as the methyl tert-Butyl ether (MTBE) and ethyl tert-Butyl ether (ETBE).

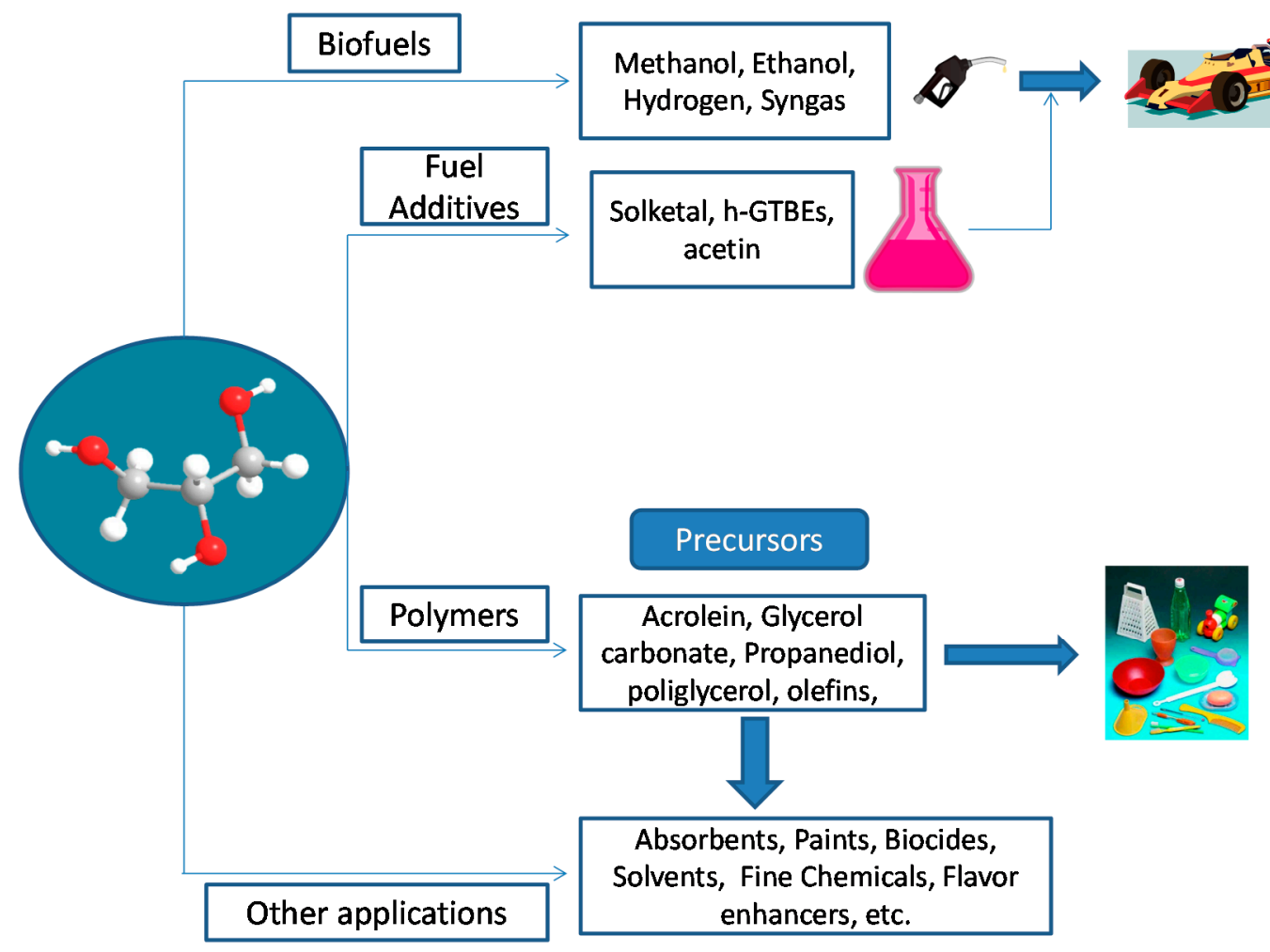

Figure 3. Main application fields of glycerol derivatives.

In fact, several researches have evaluated the effects of glycerol-derived oxygenated fuel additives on diesel engines [32-36]. One of the most promising fuel additives, taking into account the cost of production, is a mixture of di-tert-Butyl glycerol ethers (DTBGs) and tri-tert-Butyl glycerol ether (TTBG), the so-called h-GTBE, obtained by the etherification reaction of glycerol, either with isobutene (IB) or with tert-Butyl alcohol (TBA). This reaction has been studied mainly over heterogeneous catalysts due to the several advantages that they exhibit in comparison to homogeneous ones. For example, heterogeneous catalysts can be easily separated by a simple filtration or a centrifugation process. Then, the recovered catalyst can be employed again in subsequent reactions. Furthermore, the use of homogeneous catalysts can lead to different drawbacks such as the corrosion of the reaction systems (pipes, reactors, etc.), the necessity of a neutralization step if the use of mineral acids is required for the reaction to take place, and/or the impossibility of reusing the catalyst. Thus, despite the large number of applications of homogeneous catalysts, their substitution for heterogeneous ones with similar functionalities is becoming essential.

Thus, the present review mainly overviews the state-of-the-art production of glycerol tert-Butyl ethers either with IB or TBA on heterogeneous catalysts. Specifically, the influence exhibited by different catalytic processes and reaction conditions, as well as the characteristic of the catalysts on the values of conversion and yield to the desired products, have been compiled and discussed. 


\section{Etherification of Glycerol to Produce Oxygenated Fuel Additives}

As is well-known, glycerol (G) cannot be added to fuels for different reasons. On the one hand, the high temperatures reached in the motor engines promote the glycerol polymerization as well as the formation of different products with high toxicity, such as acrolein. On the other hand, the low solubility of glycerol into fuels makes its use as fuel additive unsuitable. However, the glycerol ethers are able to be employed as oxygenated additives, as aforementioned. In addition, they can be used as industrial solvents and cleaning agents in industry [2].

\subsection{Etherification of Glycerol with Isobutene}

Scheme 2 shows the reaction pathways for the etherification of glycerol with isobutene (IB). It is accepted that the tert-Butylation of glycerol with isobutene needs of acid catalysis. The formation of the mono-tert-Butyl, di-tert-Butyl, and tri-tert-Butyl glycerol ethers occurs by consecutive reactions in which glycerol reacts with isobutene. Logically, the etherification of glycerol is preferred on primary hydroxyl groups, 1-mono-tert-Butyl glycerol ether (1-MTBG) > 2-mono-tert-Butyl glycerol ether (2-MTBG).

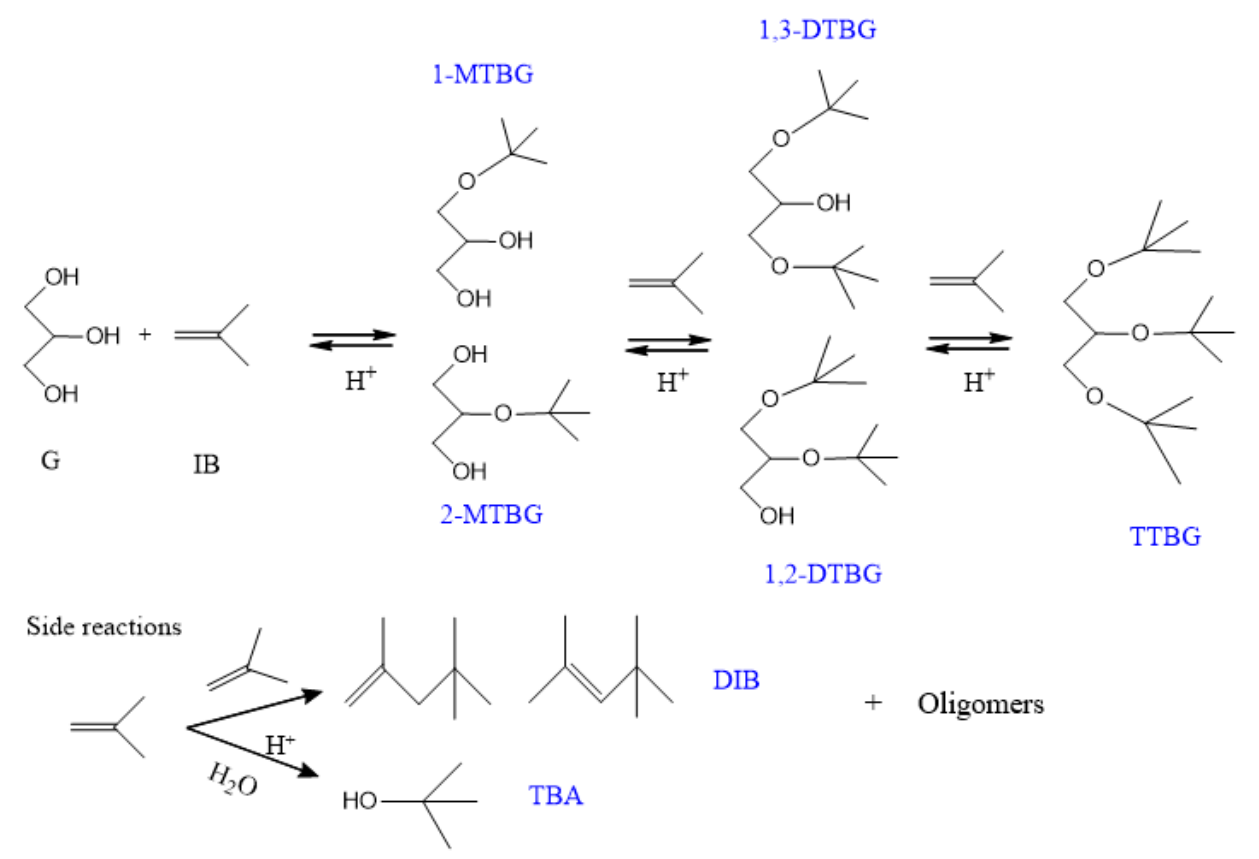

Scheme 2. Reaction pathways for the etherification of glycerol with isobutene.

In the beginning, this reaction was developed using p-toluenesulfonic acid and phosphorustungstic acid as homogeneous catalysts, obtaining high glycerol conversion values, $89 \%$ and $79 \%$, respectively [37]. However, the heterogeneous catalysis is much more favorable considering operational, economic, and environmental aspects. Table 1 compiles the most relevant catalytic results to date in the glycerol etherification with IB. Thus, Karinen and Krause [38] studied the optimal reaction conditions for the etherification of glycerol with IB over a commercial ion-exchange macroreticular resin, the Amberlyst 35. They observed that the best results, regarding the formation of the DTBGs (60\% of selectivity), were obtained at $80{ }^{\circ} \mathrm{C}$ reaction temperature and a stoichiometric molar ratio IB/G. A higher amount of initial $\mathrm{G}$ caused a mass transfer limitation owing to the high viscosity of the mixture, whereas an excess of IB favored its oligomerization. Furthermore, the authors observed that the addition of TBA to the reaction mixture improved the mass transfer between the phases, and also reduced the oligomerization of IB.

In the same line, Klepáčová et al. [39] reported the solventless etherification of glycerol with isobutene or tert-Butyl alcohol on different ion-exchange macroreticular resins, Amberlyst 15 and 35 , and also over two large-pore zeolites, HY and H-Beta. Some important aspects were found in 
this research. On the one hand, the water obtained in the reaction of glycerol with tert-Butyl alcohol deactivated the acid sites of the ion exchange resins. On the other hand, if IB was employed as a reactant, an increase in the reaction temperature promoted a secondary reaction, such as the dimerization of isobutene, as well as the disproportion of the glycerol ethers formed. Regarding the behavior of the catalysts, the best results were obtained over the acid macroreticular ion exchange resins $(100 \%$ of glycerol conversion and $92 \%$ of selectivity to h-GTBE) using IB as a reactant at the following reaction conditions: $60{ }^{\circ} \mathrm{C}, 7.5 \mathrm{wt} . \%$ of catalyst, $8 \mathrm{~h}$, and a IB/G molar ratio of $4: 1$. In addition, the authors concluded that zeolites are not suitable catalysts for this reaction because a rapid deactivation occurred due to the small size of their pores, although good results of yield to DTBGs were obtained, $65.8 \%$ and $80.6 \%$ for HY and H-Beta, respectively. The same catalysts were tested employing a solvent, observing a change in the polarity and an homogenization of the reaction mixture [40]. As a consequence, the best results were obtained over on the HY zeolite $\left(90 \%\right.$ and $0.18 \mathrm{~mol} \cdot \mathrm{L}^{-1}$ of DTBGs) after $8 \mathrm{~h}$ of reaction. However, in the presence of a solvent, TTBG was never obtained, corroborating the influence of the pore size. According to the author, and from a technological point of view, zeolites would not be suitable catalysts for this reaction due to the fact that they are easily deactivated and also due to the high prices that they exhibit in comparison to the ion exchange resins.

The possibility of partially neutralizing the acidity of A-15, in order to suppress the isobutene oligomerization, was studied by Lee et al. [41,42]. They observed that a partial substitution of acidic protons with $\mathrm{Na}^{+}, \mathrm{Ag}^{+}, \mathrm{Mg}^{2+}$, and $\mathrm{Al}^{3+}$ gave rise to a decrease in the rate of all the processes involved in the reaction, including the IB oligomerization that was efficiently suppressed, obtaining less than $50 \%$ of di-isobutene (DIB). Very recently, Bozkurt et al. [43] studied the influence of the degree of sodium-exchange in Amberlyst-15 acidity, evaluating the behavior of these catalysts in batch and flow reactors. Authors observed from the ammonium-temperature programmed desorption (TPD) measurements and density functional dispersion (DFT) calculations, that a substitution of the protons of the sulfonic groups in A- 15 with $\mathrm{Na}^{+}$cations promoted a decrease in acidity, as was expected, but also promoted an increase in the strength of these acid sites. Thus, in batch reactors, a total conversion was attained, the higher the Na-exchange in A-15, the higher the selectivity to h-GTBE. Furthermore, the IB oligomerization was suppressed in almost one order of magnitude for the catalyst with the highest $\mathrm{Na}$ exchange. In addition, to elucidate the changes in the reaction network, the authors performed measurements in a once-through flow reactor at low conversions. The results showed that mono-tert-Butyl glycerol ethers (MTBGs) and DIB were the first products obtained on A-15, while DTBGs and TTBG also became primary products on sodium-exchange counterpart catalysts.

Melero et al. [44] studied the reaction over different sulfonic acid-functionalized mesostructured silicas, attaining higher yields than those obtained over commercial ion-exchange resins (A-15 and A-36). The optimal experimental conditions were chosen by statistical multivariate analysis, obtaining $92 \%$ of yield to h-GTBE over an arylsulfonic-SBA- 15 at $75{ }^{\circ} \mathrm{C}$, a molar ratio IB/G of 4 , and $4 \mathrm{~h}$ of reaction. The absence of IB oligomers, despite an excess of IB (molar ratio IB/G $=4$ ) being employed, contradicts the previous results reported by Karinen and Krause on the A-15 [38]. The authors explained this behavior was due to the moderate strength of the acid sites, as well as their location on the mesostructured silicas.

Likewise, several modified zeolites have been employed as catalysts in this reaction. Zhao et al. [45] performed the reaction over rare earth $\left(\mathrm{La}^{3+}, \mathrm{Ce}^{3+}, \mathrm{Nd}^{3+}\right.$, and $\left.\mathrm{Eu}^{3+}\right)$ modified $\mathrm{H} \beta$ zeolites prepared by ion exchange. Among all the modified $\mathrm{H} \beta$ zeolites, the best catalytic results, $67 \%$ of yield to h-GTBE, were obtained over that modified with Neodymium at $70{ }^{\circ} \mathrm{C} ; \mathrm{IB} / \mathrm{G}$ molar ratio of 3 and $2 \mathrm{~h}$ of reaction time. The highest activity attained on this catalyst is related to the highest acidity that it also exhibited. Xiao et al. [46] studied the modification of an HY zeolite by acid washing with citric acid and nitric acid, observing an improvement in the catalytic activity in comparison with the unmodified HY zeolite, that was associated with the modification of its textural properties, although the influence of the changes in acidity also observed should not be ruled out. González et al. [47] proposed the functionalization with sulfonic groups of several zeolites, such as Beta, ZSM-5, mordenite, 
and a commercial montmorillonite K-10. The incorporation of sulfonic acid groups was different on each zeolite, mainly due to the dealumination degree suffered by the zeolites as a consequence of the acid treatment. Be that as it may, the presence of sulfonic acid sites improved the catalytic activity of the zeolites studied. The influence of the microwave irradiation in the sulfonation of a Beta zeolite and also of a SBA-15 was also studied [48]. Independently of the heating method (e.g., microwave irradiation or conventional heating), complete conversion and a high selectivity to TTBG ethers (32-36\%) were obtained on the functionalized beta zeolites. Hence, those results demonstrated that the microporosity of the zeolite was not difficult in the formation of TTBG if the material exhibited an adequate amount and strength of acid sites. Mesoporous silicas, MCM-41, SBA-15, and HMS, modified by different methodologies (e.g., introducing aluminum into the structure, incorporating phosphorous species or sulfonic groups) was also studied by the same authors [49]. The best results ( $100 \%$ of glycerol conversion and $84 \%$ of selectivity to h-GTBE) were obtained over the sulfonated HMS silica synthesized using dodecylamine (dda) as a surfactant. They concluded that, despite the fact that the aluminum and phosphorous incorporation improved the acidity of the catalysts, this was not strong enough to achieve a satisfactory selectivity to h-GTBE $(<50 \%)$. Furthermore, the catalysts suffered some deactivation due to the reagents and reaction products blocked the pores. In order to avoid the deactivation suffered by these micro and mesoporous materials, González et al. [50] dealt with the synthesis of sulfonic acid-functionalized aerogels in a subsequent research. The best catalytic results $(100 \%$ conversion and $75 \%$ selectivity to h-GTBE) were achieved over a sulfonated aerogel (MwS-AG) at $75^{\circ} \mathrm{C}$ of temperature, an IB/G molar ratio of 4 and $24 \mathrm{~h}$ of reaction time. In addition, the catalyst was stable after four cycles.

Frusteri et al. [51-53] studied the catalytic performance of Hyflon®perfluorosulfonic ionomers supported on several spherical silicas in the etherification of glycerol with IB, attaining a yield to h-GTBE over Hyflon®/ES70Y of $89 \%$. According to the authors, factors such as a strong ionomer-silica interaction, a high accessibility to the active centers of the catalysts, and also hydrophobic surface properties are the influential factors on the catalytic behavior. In order to further shift the equilibrium of the reaction the formation of h-GTBE, a new charge of catalyst was added to the final reaction mixture, with a decrease taking place in the amount of MTBGs in the mixture from $28.3 \%$ to $9.9 \%$ [52].

Catalysts based on carbon have also been reported in this reaction. Zhao et al. [54] proposed the synthesis of an amorphous carbon-based catalyst obtained by the sulfonation of partially carbonized peanut shells. This catalyst showed a very good catalytic performance in the reaction, achieving total conversion of glycerol and selectivity to h-GTBE of $92 \%$ at $70{ }^{\circ} \mathrm{C}$, an IB/G molar ratio of 4 , and $2 \mathrm{~h}$ of reaction time. Zhou et al. [55] synthesized a sulfonated graphene catalyst by grafting aryl radicals containing sulfonic groups onto the two-dimensional surface of graphene. This catalyst exhibited an almost total conversion of glycerol and a selectivity value to TTBG of $59 \%$, at $70{ }^{\circ} \mathrm{C}$, an IB/G molar ratio of 6 , and $7 \mathrm{~h}$ of reaction time. Furthermore, these authors reported a simple methodology to obtain the desired ethers from the reaction mixture, consisting in the extraction of the non-desired products using fresh glycerol.

Voicu et al. [56] evaluated the effect of different types of emulsifiers in the reaction medium, employing a hydrated silicotungstic acid as the catalysts. Of all the emulsifiers employed, the best results were obtained using an amphoteric ammonium quaternary salt $\left(C_{19}\right)$. This amphoteric emulsifier improved both the glycerol conversion and the selectivity to di- and tri-tert-Butyl glycerol ethers, reducing the dimerization of IB. 
Table 1. Compilation of the best heterogeneous catalytic results on the glycerol etherification with IB.

\begin{tabular}{|c|c|c|c|c|c|c|c|c|}
\hline \multirow[b]{2}{*}{ Catalyst $^{\text {a }}$} & \multicolumn{5}{|c|}{ Reaction Conditions } & \multirow{2}{*}{$\underset{(\mathrm{mol} \%)}{\mathrm{X}_{\mathrm{G}}}$} & \multirow{2}{*}{$\begin{array}{l}S_{\mathrm{h}-\mathrm{GTBE}} \\
(\mathrm{mol} \%)\end{array}$} & \multirow[b]{2}{*}{ Ref. } \\
\hline & $\begin{array}{c}\mathrm{T} \\
\left({ }^{\circ} \mathrm{C}\right)\end{array}$ & $\begin{array}{l}\mathrm{P}^{\mathrm{b}} \\
\text { (bar) }\end{array}$ & $\begin{array}{l}\text { Cat. Loading } \\
\text { (wt.\% of G) }\end{array}$ & $\begin{array}{c}\mathrm{IB} / \mathrm{G} \\
\mathrm{Mol} / \mathrm{mol}\end{array}$ & $\begin{array}{l}\text { Time } \\
\text { (h) }\end{array}$ & & & \\
\hline $\begin{array}{l}\text { p-toluenesulfonic } \\
\text { acid }\end{array}$ & 90 & 1.4 & 2.16 & 2 & 5 & 89 & 47 & [37] \\
\hline $\begin{array}{c}\text { Amberlyst-15 } \\
\text { (A-15) }\end{array}$ & 80 & 15 & $1 \mathrm{~g}$ & 4 & 7 & $>95$ & 97 & [38] \\
\hline $\begin{array}{l}\text { Amberlyst-39 } \\
\text { wet }\end{array}$ & 60 & Autoge & 7.5 & 4 & 8 & 100 & 93 & [39] \\
\hline A-15 in dioxane & 60 & Autoge & 7.5 & 4 & 8 & 79 & 47 & [40] \\
\hline $\begin{array}{c}\mathrm{Ag}(62) \mathrm{A}-15^{\mathrm{c}} \\
\text { powder }\end{array}$ & 60 & 20 & 7.5 & 4 & 20 & $>90$ & 92 & [41] \\
\hline $\mathrm{Na}(51) \mathrm{A}-15^{\mathrm{c}}$ & 60 & 20 & 7.5 & 4 & 20 & 99 & 90 & [42] \\
\hline $\begin{array}{l}\text { 0.3MNa-exchange } \\
\text { A-15 }\end{array}$ & 75 & $10-15$ & 7.5 & 3 & 6 & 100 & 92 & [43] \\
\hline Ar-SBA-15 & 75 & $8+\mathrm{VLE}$ & 5 & 4 & 4 & 100 & 92 & [44] \\
\hline Zeolite $\beta+\mathrm{Nd}^{+3}$ & 70 & 15 & 6 & 3 & 2 & 93 & 75 & [45] \\
\hline $\begin{array}{l}\text { Zeolite } \mathrm{Y}+1 \mathrm{M} \\
\text { citric }^{\text {acid }}{ }^{\mathrm{c}}\end{array}$ & 80 & Autoge & 1 & 4 & 5 & 82 & 57 & [46] \\
\hline $\begin{array}{c}\text { Zeolite } \\
\beta-M w S(1.4)\end{array}$ & 75 & $10+$ VLE & $0.5 \mathrm{~g}$ & 4 & 48 & 100 & 90 & $\begin{array}{l}{[47,} \\
48]\end{array}$ \\
\hline HMS(dda)-S & 75 & $10+$ VLE & $0.5 \mathrm{~g}$ & 4 & 24 & 100 & 84 & [49] \\
\hline MwS-AG & 75 & $10+$ VLE & $0.5 \mathrm{~g}$ & 4 & 24 & 99 & 75 & [50] \\
\hline 730SS1 & 70 & Autoge & 7.5 & 3 & 17 & 100 & 89 & [51] \\
\hline Hyflon ${ }^{\circledR} /$ ES70Y & 70 & Autoge & 7.5 & 3 & 17 & 100 & 93 & [52] \\
\hline $\begin{array}{l}\text { Sulfonated } \\
\text { peanut shell }\end{array}$ & 70 & 15 & 6 & 4 & 2 & 100 & 92 & [54] \\
\hline SG & 70 & 10 & 2 & 6 & 7 & 99 & 96 & [55] \\
\hline $\begin{array}{c}\mathrm{HSiW} \cdot 20 \mathrm{H}_{2} \mathrm{O} \text {, in } \\
0.7 \% \mathrm{C}_{19}\end{array}$ & 80 & Auto & 5 & 3 & 5 & 99 & 90 & [56] \\
\hline
\end{tabular}

a. Ar-SBA-15: Arenesulfonic-SBA; HMS (dda): HMS synthesized using dodecylamine as surfactant; MwS-AG: Microwave sulfonated silica aerogel; 730SS1: 730 equivalent weights on spherical silica, obtained by incipient wetness; Hyflon ${ }^{\circledR} / E S 70 Y$ : Hyflon Ion S4X perfluorosulfonic ionomer supported on spherical silica (ES70Y); SG: Sulfonated graphene; $\mathrm{HSiW} \cdot 20 \mathrm{H}_{2} \mathrm{O}$, in $0.7 \% \mathrm{C}_{19}$ : silicotungstic acid hydrate in amphoteric emulsifier $\left(\mathrm{C}_{19}\right)$. b. Autoge: Autogenous pressure; VLE: Pressurizing the reactor and then to reach the vapor liquid equilibrium. c. Dioxane was employed as solvent.

Apart from the type of catalyst employed, some studies have focused their attention on the mass transfer and on the phase separation of the reaction mixture. This fact is of great importance owing to glycerol being immiscible in IB and in high ethers, as reported by Behr and Obendorf [37]. Thus, the biphasic system can be changed to a monophasic system by decreasing glycerol and increasing MTBG/h-GTBE or decreasing both glycerol and IB, while increasing mono-tert-Butyl glycerol ethers. In fact, they observed that after $40 \mathrm{~min}$, the biphasic system became monophasic with a reaction mixture composition of $40 \mathrm{wt} . \%$ DTBG, $30 \mathrm{wt} . \%$ MTBG, and $5 \mathrm{wt} . \%$ of glycerol (IB and TTBG were not observed). This prototype was improved by Liu et al. [57,58], demonstrating that the tert-Butyl ethers of glycerol are soluble with each other in the temperature range of $70.2-100.2{ }^{\circ} \mathrm{C}$. In addition, MTBG and glycerol are perfectly mixed under all concentrations tested, whereas the h-GTBE were partially soluble with glycerol, rising slightly when the temperature increased.

\section{Experimental Designs Reported to Date for Glycerol Etherification with IB}

Regarding the process designs and experimental settings, very few studies on the production of glycerol ether in continuous reactors, over heterogeneous catalysts, have been published to date [43]. Di Serio et al. [59] have reported a process for the production of h-GTBE employing the Amberlist-15 
as a catalyst, in which those desired products were extracted by using biodiesel. This blend of biodiesel/h-GTBE can be employed directly as a diesel additive. More recently, Liu et al. [60] obtained the h-GTBE employing an ion exchange resin, NKC-9, as catalyst. After the reaction, the MTBGs were extracted with fresh glycerol, whereas residual glycerol of the reaction was washed with water. Furthermore, the IB and DIB produced during the reaction were separated by distillation, whereas the residual glycerol, after washing with water, and the recovered IB were recirculated in order to be employed again as reactants. Furthermore, the authors carried out a study on the feasibility of the process using a mathematical model, which included the cost related to the raw materials, the equipment, utilities, operating, and maintenance, concluding that the production of these additives can be very promising from the economical point of view if the IB price is below $1.2 \$ / \mathrm{Kg}$, considering that the cost to produce the glycerol ethers is $1 \$ / \mathrm{Kg}$. Regarding the possibility of using crude glycerol and IB from the $\mathrm{C}_{4}$ fraction of crude oil, very few studies have been published [61,62], and only at laboratory scale.

\subsection{Etherification of Glycerol with tert-Butyl Alcohol}

In recent years, the possibility of using TBA instead of isobutene to obtain the glycerol tert-Butyl ethers has gained importance. There are different reasons to explain this fact. Firstly, isobutene is obtained in the catalytic cracking of crude oils. Concretely, 1-butene, cis/trans-2-butene, and IB conform the crude oil $\mathrm{C}_{4}$ fraction. Therefore, their price depends directly on the crude prices, in addition to coming from a non-renewable source. Secondly, in order to keep the IB in the liquid phase in the etherification reaction, the use of additional pressure is required. In fact, as aforementioned, the mass transfer between the two phases is a limiting factor in this reaction, making the use of a solvent advisable to achieve a better catalytic performance. Regarding environmental aspects, the solventless reaction has to be promoted. Last but not least, an important drawback is the secondary reactions of $\mathrm{IB}$, promoted by strong acid sites, giving rise to a decrease in the selectivity to the desired products, as aforementioned.

All these disadvantages can be palliated by using tert-Butyl alcohol, which is liquid at the reaction temperatures usually employed, allowing the mass transfer between the phases, acting itself as both solvent and reactant, avoiding the use of solvents capable of dissolving glycerol, with the technological problems that this fact implies, as well as typical drawbacks of a complex three-phase system. Likewise, the oligomerization of IB can be diminished, and the use of high pressure to carry out the reaction is not needed. Furthermore, TBA is currently obtained from the polypropylene production.

Analogously to the etherification of glycerol with IB, the etherification with TBA requires catalysts with acid sites, see Scheme 3. It is generally accepted that the reaction mechanism occurs via a rapid protonation on acid sites of TBA, which, on losing a water molecule, generates a tertiary carbocation. This carbocation reacts with glycerol, generating the MTBGs in the first step of the reaction. Analogously, the reaction of another TBA molecule with mono-tert-Butyl glycerol ethers generates the di-substituted ones (DTBGs), which, reacting with TBA, produces the TTBG in a subsequent reaction. Hence, water is formed in every step of the reaction, and IB can be also obtained by TBA dehydration. Hence, there are two aspects that must be taken into account employing TBA as a reactant. Firstly, the reaction is controlled by the thermodynamic equilibrium, which limits the maximum yield to the reaction products. Secondly, the formation of water in every step, Scheme 3, can promote the hydrolysis of the ether bonds formed, shifting the equilibrium to the left. In addition, the water molecules can solvate the acid sites, promoting a faster deactivation of the catalysts.

Thus, Klepàcová et al. [39] studied the etherification reaction with IB and TBA over two different ion exchange resins, A-15 and A-35, at two temperatures, 60 and $90{ }^{\circ} \mathrm{C}$. The highest yield to h-GTBE $(88.7 \%)$ was obtained over A-35 with IB, whereas the yield value using TBA was only $6.5 \%$. Similar results were reported by González et al. [63] over several zeolitic materials. Klepàcová et al. [64] also reported the optimal experimental conditions for the reaction (i.e., $75^{\circ} \mathrm{C}$ of reaction temperature and a high TBA/G molar ratio), which is logical according to the Le Chatelier principle. In fact, as can be seen 
in Table 2, temperatures in the range of $60-120^{\circ} \mathrm{C}$ and a TBA/G molar ratio of 4 are the most typical conditions employed by the researchers. However, Chang et al. [65] reported a one-step synthesis and separation of the h-GTBE, consisting in employing very high temperatures $\left(\sim 190^{\circ} \mathrm{C}\right)$, obtaining the reaction products separated in two phases. From the organic phase, the h-GTBEs were separated from $\mathrm{IB}$ and its oligomers by distillation below $225^{\circ} \mathrm{C}$, directly obtaining the oxygenated additives.

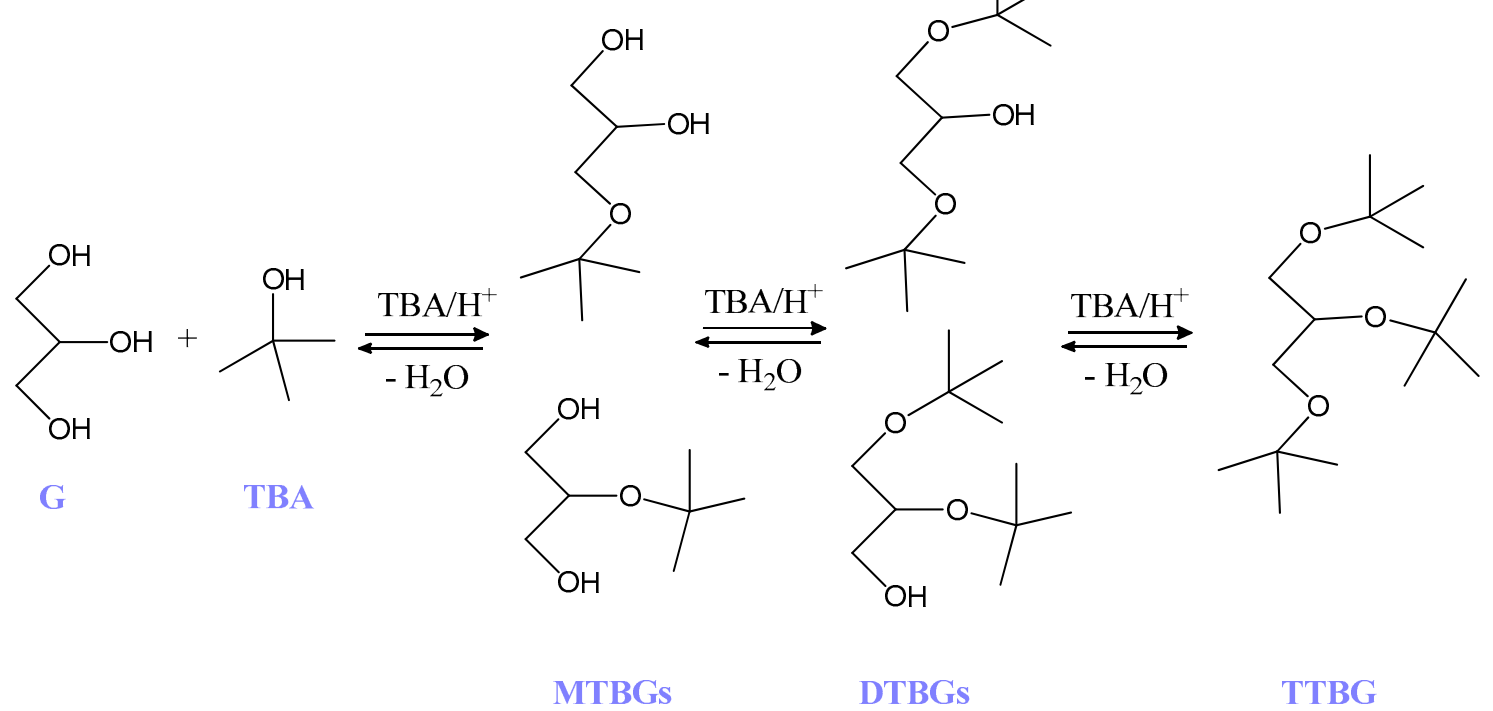

Scheme 3. Reaction pathways for the glycerol etherification with TBA.

In addition to the high TBA/G molar ratio, another strategy employed to shift the equilibrium to the formation of the desired products is the elimination of the water formed. Thus, Frusteri et al. [66] performed the reaction over silica-based catalysts, taking two ion exchange resins, SAC-13 and A-15, as reference. The best results were obtained over A-15 (yield to h-GTBE $=28 \%$ ). The authors proposed two main reasons for the low formation of TTBG: the steric hindrance and the water formation during the reaction. In order to corroborate this, they proposed an experiment consisting of stopping the reaction after $6 \mathrm{~h}$, to dehydrate the reaction mixture by adding zeolites, and then running again for another $6 \mathrm{~h}$, obtaining an increase in DTBGs from $28 \%$ to $41 \%$. This result clearly demonstrated that the presence of water makes the formation of h-GTBE difficult, in agreement with Klepàcová et al. [64]. To overcome the problem of the presence of water in the reaction mixture, Cannilla et al. $[67,68]$ employed a water permselective membrane, allowing the equilibrium to be shifted toward the formation of poly-ethers. This membrane selectively removed the water formed by the recirculation of the gas phase. Acid catalysts, prepared by the impregnation of an ethanolic solution of Hyflon Ion S4X perfluorosulfonic ionomer on microspherical silica, were compared with Amberlist-15 [67], obtaining a better catalytic performance on the Hyflon supported catalysts with the use of the membrane, because of its higher hydrophilicity and a better accessibility to the active sites. Furthermore, the use of a membrane able to remove water selectively allowed thermodynamics constrains to be overcome, attaining total glycerol conversion and selectivity values to h-GTBE of $70 \%$.

Apart from the ion exchange resins, other catalytic systems have been studied in order to overcome the limitations of these types of resins, such as the lack of thermal stability, the fact that they can be swelled and shrunk in organic media, and their hydrophobic character, since the sulfonic acid groups are the only hydrophilic part of the structure. The hydrophobic character promotes a faster deactivation by the generation of water, since this water solvates the sulfonic acid groups [66]. Thus, catalytic systems based on carbon, mainly prepared from biomass and sulfonated by different strategies, have gained importance. Thus, Gonçalves et al. [69] evaluated the behavior of sulfonated carbons prepared from agroindustrial wastes, showing a high catalytic performance. In fact, with the sugar cane 
bagasse-based catalyst, a glycerol conversion value of $80.9 \%$ and selectivity to h-GTBE of $21.3 \%$ were attained after $4 \mathrm{~h}$ of reaction time, at $120^{\circ} \mathrm{C}$, and using a $5 \mathrm{wt} . \%$ of catalyst loading. The hydrophilic character of the carbons makes possible the absorption of the water generated during the reaction, palliating the negative influence that this water usually has in the catalytic activity and selectivity to the h-GTBE. In this line, Carvalho et al. [70] prepared sulfonated carbons from rice husk by different acid treatments (i.e., using sulfuric acid $6 \mathrm{M}$, concentrated sulfuric acid, and also the vapor of concentrated sulfuric acid). From all the catalysts studied, the sulfonated ones using concentrated sulfuric acid under reflux exhibited the best catalytic behavior ( $53 \%$ of glycerol conversion and $25 \%$ of selectivity to h-GTBE), due to the highest acidity that this solid exhibited in comparison to the other sulfonated carbons. Gonçalves et al. [71] prepared sulfonated black carbons from coffee grounds, following a similar procedure to that employed by Carvalho [70]. Thus, by the sulfonation of the carbons with fuming sulfuric acid, an incorporation of $8 \%$ of sulfur and an acidity value of $4.2 \mathrm{mmol} \mathrm{H}^{+} / \mathrm{g}$, were obtained. The yields to MTBG and h-GTBE obtained with these solids were about $40 \%$ and $20 \%$, respectively. Furthermore, the active groups of the acid black carbons exhibited a high stability, allowing them to be used in consecutive reactions. Gonçalves et al. [72] also studied the preparation of carbons by hydrothermal treatment of glycerol, that was obtained in the biodiesel production, and sulfuric acid. The best catalytic activity was obtained on the carbon prepared with a glycerol:sulfuric acid ratio of 1:3, attaining yields to the high ethers around $20 \%$, similar to those obtained over the commercial Amberlyst-15. Furthermore, the catalysts were able to be reused in subsequent reactions (up to eight) without an appreciable loss of activity.

Pico et al. [73,74] studied the capability of several ion exchange resins, A-15, A-200, and Amberlite IRC-50, to be reused, concluding that no significant losses of activity were observed for the spent catalysts. The highest activity was obtained over A-15 $\left(\mathrm{X}_{\mathrm{G}}=80 \%\right)$, and was explained on the basis of its better textural properties in addition to its well-known acidity. A negligible loss of activity was also observed by Magar et al. [75] over several acidic clay catalysts after several uses. Concretely, with a fresh montmorillonite KSF/O clay catalyst, total glycerol conversion was attained due to its highest acidity. Celdeira et al. [76] reported the sulfonation of aluminum pillary clay and niobia (HY-340 CBMM) by two different methods, a treatment with $30 \%$ aqueous sulfuric acid solution or a treatment with fuming sulfuric acid, achieving a higher sulfur incorporation with fuming sulfuric acid, attaining a yield to h-GTBE of 38.6 with 95\% glycerol conversion. Srinivas et al. [77] prepared cesium exchanged tungstophosphoric acid (CsTPA), supported on tin oxide with cesium exchanges between $10 \%$ and $30 \%$. The acidity of the solids increased up to $20 \%$ of cesium exchange, being the solid with the highest acidity and also exhibiting the best catalytic performance $\left(X_{G}=91 \%\right.$ and $\left.S_{h-G T B E}=44 \%\right)$ after only one hour of reaction time. The authors proposed a plausible mechanism for the reaction, in which Bronsted acid sites on CsTPA were responsible for activating tert-Butanol, while Lewis acid sites in the support activated the glycerol, resulting in the formation of mono-ethers. The successive transformation of glycerol to h-GTBE is possible due to the regeneration of acid sites. Furthermore, the authors revealed that these catalysts were also water tolerant.

In addition to the acidity of the catalysts, the textural properties also exhibit a great importance in this reaction, due to the large size of the h-GTBE molecules. Klepàcová et al. [64] compared Amberlyst ion-exchange resins either in gel or macroreticular form, concluding that the macroreticular ones with a high degree of crosslinking exhibited a higher activity due to their larger pores allowing the formation of the TTBG.

The effect of the textural properties on h-GBTE production has also been studied over zeolitic materials. Thus, González et al. [63] studied the effect of hierarchical porosity in a $\beta$-zeolite, obtaining a better catalytic behavior than on the conventional zeolite, due to the greatest accessibility of the reactants to the active sites. Furthermore, the hierarchical zeolite after a fluorinated treatment improved the selectivity to h-GTBE, due to the increase in the number of strong acid sites that it exhibited. The decisive role of the Bronsted acidity and porosity was corroborated by the authors [78], studying several type of zeolites, such as mordenite, beta, and ZSM- 5 zeolites modified by protonation, 
dealumination, desilication-protonation, lanthanum exchange, and fluorination. Thus, the best catalytic behavior $\left(\mathrm{X}_{\mathrm{G}}=75 \%\right.$ and $\left.\mathrm{S}_{\mathrm{h}-\mathrm{GTBE}}=37 \%\right)$ was associated with the highest acidity and the larger pore size of the zeolite. Likewise, Simone et al. [79] achieved better results on nanostructured MFI-type zeolites than on traditional zeolites. The nanosponge-like morphology of the zeolites consisted of a three-dimensional disordered network of MFI layers with $2.5 \mathrm{~nm}$ thickness supporting each other, obtaining the highest selectivity to TTBG $(10 \%)$ with unilamellar MFI containing a SI:Al ratio of 100, which exhibited a high proportion of the acid sites on the external surface, enabling a favorable accessibility of the reactants to these sites. Estevez et al. [80] dealuminated a HZSM-5, with different $\mathrm{Si}: \mathrm{Al}$ ratio, and a $\mathrm{HY}$ zeolite by acid treatment with $\mathrm{HCl}$ and functionalized them with two organosilica precursors: 3-mercaptopropyltrimethoxysilane $(\mathrm{M})$, containing thiol groups, and 2-(4-chlorosulfonylphenyl)ethyltrimethoxysilane (C), which contains sulfonic acid groups. The solids with highest acidity were those functionalized with $\mathrm{M}$, also exhibiting the highest yields to h-GTBE $(13 \%)$, using microwave as a way of heating. Furthermore, the textural properties of the zeolites played an important role in their activity (i.e., HY, with the largest channel size, was more active than the HZSM-5). Very recently, Miranda et al. [81] explored the impact of the size of the crystals and the structures of four types of zeolites (i.e., FAU, MOR, BEA, and MFI). They proposed that the reaction followed an Eley-Rideal mechanism in which the total amount of Bronsted acid sites is decisive, but also the shape selectivity. In fact, the formation of DTBGs was rather low in comparison to that obtained on meso- and macroporous acid catalysts. Veiga et al. [82] evaluated the catalytic performance of zeolites subjected to a steaming treatment and acid leaching to eliminate extra-framework aluminum, reporting that the hydrophobicity-hydrophilicity relationship of the catalysts had great influence on the catalytic activity, in addition to their acid and textural properties. The influence of the hydrophobic-hydrophilic character of the catalysts was also claimed by Estevez et al. [83], by studying sulfonated silica-based and sulfonated organosilica-based materials exhibiting different acidities, textural properties, and also different hydrophilic-hydrophobic character. The acidity and hydrophilic character were key parameters for the catalytic behavior. In fact, the best results $\left(\mathrm{Y}_{\mathrm{h}-\mathrm{GTBE}}=28 \%\right)$ were obtained over the hybrid silica exhibiting the highest acidity, the $\mathrm{S}_{50} \mathrm{TS}_{50} \mathrm{O}$, at $75^{\circ} \mathrm{C}$ and autogenous pressure. In the same line, Estevez et al. [84] reported a yield value to h-GTBE of $21 \%$ after $15 \mathrm{~min}$ of reaction using microwave as a way of heating in the reaction, on organosilica-aluminum phosphates that exhibited the highest acidity and a similar proportion of meso- and macropores. Furthermore, the hydrophilic character of the solids avoided the rapid deactivation observed on Amberlyst- 15 .

Table 2. Compilation of studies on glycerol etherification with TBA over heterogeneous catalysis.

\begin{tabular}{|c|c|c|c|c|c|c|c|c|}
\hline \multirow{2}{*}{ Catalyst $^{a}$} & \multicolumn{5}{|c|}{ Reaction Conditions } & \multirow{2}{*}{$\underset{(\mathrm{mol} \%)}{\mathrm{X}_{\mathrm{G}}}$} & \multirow{2}{*}{$\begin{array}{l}\mathrm{S}_{\mathrm{h}-\mathrm{GTBE}} \\
(\mathrm{mol} \%)\end{array}$} & \multirow{2}{*}{ Ref. } \\
\hline & $\begin{array}{c}\mathrm{T} \\
\left({ }^{\circ} \mathrm{C}\right)\end{array}$ & $\begin{array}{l}\mathrm{P}^{\mathrm{b}} \\
\text { (bar) }\end{array}$ & $\begin{array}{l}\text { Cat. Loading } \\
\text { (wt.\% of G) }\end{array}$ & $\begin{array}{l}\text { TBA/G } \\
\mathrm{Mol} / \mathrm{mol}\end{array}$ & $\begin{array}{l}\text { Time } \\
\text { (h) }\end{array}$ & & & \\
\hline A-15-dry & 60 & Auto & 7.5 & 4 & 8 & 79 & 19 & [39] \\
\hline $\begin{array}{l}\text { Hierarchical-Beta } \\
\text { zeolite }\end{array}$ & 75 & Auto & 5 & 4 & 24 & 77 & 35 & [63] \\
\hline A-35-dry & 90 & Auto & 7.5 & 4 & 8 & 69 & 24 & [64] \\
\hline A-70 & 190 & Auto & $7.5-10$ & 2 & 8 & 60 & $37^{*}$ & [65] \\
\hline A-15 & 70 & 1 & 7.5 & 4 & 6 & 94 & 30 & {$[66]$} \\
\hline H730/ES70Y & 80 & Auto & 7.5 & 8 & 27 & 100 & 70 & [67] \\
\hline SCC-S & 120 & Auto & 5 & 4 & 7 & 81 & 21 & [69] \\
\hline TC-L & 120 & Auto & 5 & 4 & 8 & 53 & 25 & [70] \\
\hline BCC-S5h & 120 & Auto & 5 & 4 & 5 & 70 & 29 & [71] \\
\hline BC $1: 3$ & 120 & Auto & 5 & 4 & 6 & 75 & 29 & [72] \\
\hline A-15 & 60 & Auto & 7.5 & 4 & 8 & 80 & 20 & {$[73,74]$} \\
\hline Mont-KSF/O & 110 & Auto & 27 & 20 & 6 & $\sim 100$ & $\sim 30$ & [75] \\
\hline AS-100 & 120 & Auto & 5 & 4 & 5 & 100 & 40 & {$[76]$} \\
\hline
\end{tabular}


Table 2. Cont.

\begin{tabular}{|c|c|c|c|c|c|c|c|c|}
\hline \multirow{2}{*}{ Catalyst $^{a}$} & \multicolumn{5}{|c|}{ Reaction Conditions } & \multirow{2}{*}{$\begin{array}{c}\mathrm{X}_{\mathrm{G}} \\
(\mathrm{mol} \%)\end{array}$} & \multirow{2}{*}{$\begin{array}{l}\mathrm{S}_{\mathrm{h}-\mathrm{GTBE}} \\
(\mathrm{mol} \%)\end{array}$} & \multirow[b]{2}{*}{ Ref. } \\
\hline & $\begin{array}{c}\mathrm{T} \\
\left({ }^{\circ} \mathrm{C}\right)\end{array}$ & $\begin{array}{l}P^{b} \\
\text { (bar) }\end{array}$ & $\begin{array}{l}\text { Cat. Loading } \\
\text { (wt.\% of G) }\end{array}$ & $\begin{array}{c}\text { TBA/G } \\
\mathrm{Mol} / \mathrm{mol}\end{array}$ & $\begin{array}{c}\text { Time } \\
\text { (h) }\end{array}$ & & & \\
\hline FHB & 75 & Auto & 5 & 4 & 24 & 75 & 37 & {$[78]$} \\
\hline MFI-UL-100 & 120 & Auto & 5 & 4 & 12 & 82 & 24 & [79] \\
\hline $\mathrm{BEA}_{\mathrm{NC}}{ }^{15}$ & 90 & Auto & 7.5 & 4 & 10 & 57 & 29 & [81] \\
\hline USY-650-L-2 & 90 & Auto & 7.6 & 4 & 4 & 75 & 21 & [82] \\
\hline C(10)AlPO(1.5)-250 & 85 & Auto & 5 & 4 & $\begin{array}{l}15 \\
\min \end{array}$ & 83 & 25 & [84] \\
\hline
\end{tabular}

a. SCC-S: Sulfonated carbon from sugar cane bagasse; TC-L: Sulfonated carbon from rice husk, using concentrated sulfuric acid as the sulfonating agent; BCC-S5h: Sulfonated carbon from coffee-ground waste, using fuming sulfuric acid as the sulfonating agent; BC 1:3: Sulfonated black carbon obtained by hydrothermal treatment of glycerol and sulfuric acid; Mont-KSF/O: Montmorillonite clay catalyst; AS-100: Pillary clay sulfonated with fuming sulfuric acid; $20 C_{1}$ TS: Cesium exchanged phosphotungstic acid; H730/ES70Y: Hyflon Ion S4X supported on microspherical silica; FHB: Fluorinated h-Beta zeolite; MFI-UL-100: Unilamellar MFI zeolite with Si:Al ratio of 100; M-HY: HY zeolite modified with 3-mercaptopropyltrimethoxysilane; $\mathrm{BEA}_{\mathrm{NC}}{ }^{15}$ : Nanometer size crystal BEA zeolite with Si:Al ratio of 15; USY-650-L-2: USY zeolite after two cycles of heating treatment $\left(650{ }^{\circ} \mathrm{C}\right.$ of steaming temperature $)$ and the leaching of acid sites; $\mathrm{C}(10) \mathrm{AlPO}(1.5)-250$ : Organosilica-aluminum phosphate with a molar ratio Al:P of 1.5, calcined at $250^{\circ} \mathrm{C}$ and $10 \mathrm{mmol}$ of 2-(4-chlorosulfonylphenyl)ethyltrimethoxysilane. $\mathrm{b}$ Auto: Autogenous pressure. c. Reaction carried out under microwave irradiation. * Selectivity to HCs, HCs being the products from the reaction between $\mathrm{G}$ and either IB or its oligomers.

\section{Experimental Designs Reported to Date for Glycerol Etherification with TBA}

The results overviewed in Section 2.2 are referred to as the etherification of glycerol with TBA carried out in batch reactors, under different reaction conditions. However, some studies have also been accomplished using continuous flow reactors [25]. Thus, Ozbay et al. [85] compared the results obtained over a batch reactor employing the Amberlyst- 15 as a catalyst, with those obtained using a flow reactor, obtaining similar results with both reactors, although much longer reaction times are needed with batch reactors. In addition, the effect of feed composition, reaction temperature, and pressure on the product distribution was also studied. Independently of the type of reactor employed, the generation of water during the reaction was still a problem. Authors adopted the strategy previously employed on a batch reactor, which was the use of Zeolite $4 \mathrm{~A}$ to remove water from the reaction medium, increasing the di-ethers production, as reported on batch reactors [66]. A catalytic screening in the flow reactor system was reported by Ozbay et al. [86], indicating that despite the fact that the Bronsted acidity was the most important property of the catalysts, the textural properties were also of great importance in order to avoid the diffusion resistance. The importance of textural properties was corroborated by Viswanadham et al. [87] obtaining the best results (95\% of glycerol conversion and selectivity to h-GTBE of $99 \%$ ) on a Nano-Bea zeolite in a continuous flow reactor, due to the presence of inter-crystalline mesopores, which were absent in the typical BEA zeolite. Vlad et al. [88] reported a plant-wide control for this reaction, employing a flow reactor and the Amberlyst-15 as a catalyst. The separation of the h-GTBE from the reaction mixture was achieved by two distillation columns. Authors have concluded that this process is economically feasible at the plant scale only if the mono-ethers can be recirculated for subsequent reaction with TBA. However, the separations of these MTBGs and reactants were difficult because of the formation of a water-TBA azeotrope, although this azeotrope could be broken using a suitable solvent. Thus, the authors evaluated different solvents for the separation of MTBGs, attaining good results with an extractive distillation, using 1,4-butanediol as the solvent [89]. However, due to the large number of units involved, the predicted annual cost was very high. Another option consisting in a reactive distillation column, where tert-Butyl alcohol was fed as vapor lower down the reactive zone, was also evaluated, reducing the costs almost 20 times. Very recently, Simasatitkul et al. [90] also studied the techno-economic assessment of extractive distillation 
for tert-Butyl alcohol recovery in the etherification of glycerol, reporting the use of different solvents for breaking the water-TBA azeotrope, concluding that hexyl acetate was the most suitable solvent, based not only on the environmental impact but also on the annual costs and effectiveness.

Kiatkittipong et al. [62] reported simulation and experimental studies about the use of reactive distillation to perform the reaction, finding that the suitable configuration consisted of six rectifying stages and six reaction stages. Likewise, they made a theoretical analysis about the Gibbs free energy and also performed a kinetic study of the reaction process.

Singh et al. [91] reported a system consisting of two interconnected autoclaves. In the first one, the dehydration of TBA was performed and subsequently conducted to the second autoclave, where the etherification of glycerol with IB took place.

Last but not least, the use of microwave irradiation as an alternative to conventional heating for this reaction has been considered by some authors [84,92]. In general, under microwave irradiation, similar results were obtained, although the reaction time to achieve these results was considerably reduced, making this option very promising for the near future.

\section{Blends of Glycerol Ethers Additives and (Bio)Fuel}

Diesel engines have several advantages from the energetic point of view in comparison to explosion engines. However, the combustion of diesel fuel promotes certain environmental problems that must be mitigated, such as the particulate matter emission. The oxygenated fuel additives can diminish the particulate matter and $\mathrm{NO}_{\mathrm{x}}$ emissions, since the higher amount of oxygen favors the combustion process. Nevertheless, this amount of oxygen must be controlled, because a high temperature during the combustion can promote a higher oxidation of the $\mathrm{N}_{2}$ of air, thus increasing the $\mathrm{NO}_{\mathrm{x}}$ emissions. For considering an oxygenated molecule as a potential additive for fuel formulations, it has to comply with the current regulations (e.g., European Standards (ENs) in the European Union and the American Society for Testing and Materials (ASTM) for United States and Canada) [26]. These standards collect the requirements and test methods for fuel for being employed in engines. Concretely, the EN 14214 and the ASTM D6751 compile the requirements for biodiesel.

To the best of our knowledge, the influence of glycerol ethers as oxygenated additives for (bio)fuel is still poorly studied. Noureddini et al. [93] determined the physical properties of glycerol ether-biodiesel blends, indicating that these additives are soluble in diesel and biodiesel up to $22 \%$. Furthermore, these additives showed a great potential to improve the properties of biodiesel at low temperatures (i.e., the pour point (temperature below which the liquid loss its flow characteristic) and cloud point (temperature below which the liquid forms a cloudy appearance) from $0{ }^{\circ} \mathrm{C}$ to $-5{ }^{\circ} \mathrm{C}$ and from $-3{ }^{\circ} \mathrm{C}$ to $-6^{\circ} \mathrm{C}$, respectively), and exhibiting negligible impact on fuel specific gravity. These additives also decreased the viscosity of biodiesel from 5.9 to $5.4 \mathrm{~mm}^{2} / \mathrm{s}$ for a blend of $12 \%$ of glycerol ethers and $88 \%$ of biodiesel [94]. Melero et al. [95] evaluated different oxygenated compounds (solketal, triacetin, mix of ethers, and mix of esters) in blends with biodiesel, according to the procedures listed in the EN 14214, obtaining the best results for the mixture of ethers. Thus, they improved the properties of biodiesel at low temperature and the viscosity values without affecting other important biodiesel quality parameters.

A deeper study about the behavior of several additives from glycerol (acetals, ethers, carbonates, etc.) corroborated that h-GTBE is the best additive to diminish the particulate matter and $\mathrm{NO}_{\mathrm{x}}$ emissions [36]. Furthermore, the physicochemical properties of a blend composed of $5 \%$ of biofuel ( $92.5 \%$ of a rapeseed methyl ester +7.5 of h-GTBE) and $95 \%$ of diesel comply with the EN 14214 standard and did not present any technical disadvantage for its use in the engines. In fact, a h-GTBE-diesel blend, in a proportion of 1:10, exhibited lower emissions of soot and $\mathrm{NO}_{\mathrm{x}}$ than fossil diesel without affecting the combustion process of different types of engines $[51,52,96]$.

Likewise, the influence of additives such as solketal, h-GTBE, and solketal-tert-Butyl ether (obtained by etherification between solketal and TBA) in the anti-wear properties (ASTM D 2266-01) of a low viscosity hydrocarbon oil fraction has been also evaluated [97]. From these additives, the 
solketal exhibited the best anti-wear properties, improving them by $42 \%$, in respect to the free-additive hydrocarbon oil.

Therefore, in general, the use of oxygenated fuel additives derived from glycerol and, concretely, the glycerol ethers is a matter of the economics of the production process.

\section{Conclusions}

In recent decades, the increase in the production of biodiesel has generated a huge amount of crude glycerol, whose valorization would have a great influence on the biodiesel process, making it more affordable from an economical point of view. In this context, the research of cheaper and more sustainable routes to transform glycerol into value-added products in the presence of heterogeneous catalysts are being widely developed.

Among all the routes being studied, the production of oxygenated additives for fuels has been raised as one of the most promising options. Specifically, the di- and tri-tert-Butyl ethers (h-GTBE) obtained by the reaction of glycerol, either with isobutene or tert-Butyl alcohol, improve the efficiency of the diesel combustion and reduce the particulate matter and the soot emissions with outstanding results. Furthermore, some studies foresee that these additives could be produced on industrial scale, so the search for suitable heterogeneous acid catalysts for the etherification reaction has been of great interest in recent years.

In general, a good catalyst for this reaction, implying a high yield to h-GTBE, should exhibit not only a high amount of strong acid sites but also textural properties that allow the formation of the products of the reaction, which are molecules with a large volume. In addition, an adequate hydrophobic-hydrophilic character and water-resistance are characteristics also required to avoid the deactivation of the acid sites, mainly when TBA is employed as a reactant. The study of different catalysts has been combined with the study of several engineering designs, in order to improve the production of the desired products. Thus, different alternatives, such as the use of water permselective membranes or any other sorbents of water, as well as different flow reactors have been studied.

Despite the fact that there are catalysts that have shown remarkable results in the etherification with tert-Butyl alcohol, the selectivity to h-GTBE can be improved in order to attain similar results than with isobutene. For this purpose, the shift of the reaction equilibrium to the formation of poly-substituted ethers is still a challenge. Thus, researches contemplating catalysts with ideal properties to perform the reaction, as well as new forms to remove the water formed in the reaction, could be a possible way to go forward.

Nevertheless, further research efforts are necessary in order to overcome some of the remaining challenges regarding these reactions. For example, the use of crude glycerol directly obtained from biodiesel production, as the majority of these studies employed pure glycerol as a reactant. Furthermore, the oxygenated fuel additives must be tested in different fuel blends to ensure their behavior, according to specification standards, etc. Likewise, the production of these additives on a larger scale in a feasible way needs to be achieved.

Author Contributions: R.E. conceived, reviewed, and wrote the manuscript. L.A.-D. helped in writing the manuscript. D.L. and F.M.B. supervised the manuscript.

Funding: This research received no external funding.

Acknowledgments: This research is supported by the MEIC funds (Project ENE 2016-81013-R), that cover the costs to publish in open access.

Conflicts of Interest: The authors declare no conflicts of interest. 


\section{Abbreviations}

$\begin{array}{ll}\text { A-15 } & \text { Amberlyst-15 } \\ \text { DIB } & \text { Di-isobutene } \\ \text { DOE } & \text { United States Department of Energy } \\ \text { DTBGs } & \text { Di-tert-Butyl glycerol ethers } \\ \text { EGR } & \text { Exhaust gas recirculation } \\ \text { EIA } & \text { U.S. Energy Information Administration } \\ \text { ETBE } & \text { Ethyl tert-Butyl ether } \\ \text { EN 14214 } & \text { Standard published by the European Committee for Standardization that describes the } \\ \text { FAEE } & \text { requirements and test methods for FAME } \\ \text { FAME } & \text { Fatty acid ethyl ester } \\ \text { G } & \text { Fatty acid methyl esters, components of conventional biodiesel } \\ \text { h-GTBE } & \text { Glycerol } \\ \text { IB } & \text { "High" glycerol tert-Butyl ethers (i.e., DTBGs + TTBG) } \\ \text { MTBE } & \text { Isobutene } \\ \text { MTBGs } & \text { Methyl tert-Butyl ether } \\ \text { OPEC } & \text { Methyl tert-Butyl glycerol ethers } \\ \text { TBA } & \text { Organization of the Petroleum Exporting Countries } \\ \text { TTBG } & \text { tert-Butyl alcohol } \\ \text { VLE } & \text { Tri-tert-Butyl glycerol ether } \\ & \text { Vapor liquid equilibrium }\end{array}$

\section{References}

1. Available online: https://countryeconomy.com/raw-materials/opec (accessed on 17 June 2019).

2. Nda-Umar, U.; Ramli, I.; Taufiq-Yap, Y.; Muhamad, E. An Overview of Recent Research in the Conversion of Glycerol into Biofuels, Fuel Additives and other Bio-Based Chemicals. Catalysts 2019, 9, 15. [CrossRef]

3. Hurtado, B.; Posadillo, A.; Luna, D.; Bautista, F.; Hidalgo, J.; Luna, C.; Calero, J.; Romero, A.; Estevez, R. Synthesis, Performance and Emission Quality Assessment of Ecodiesel from Castor Oil in Diesel/Biofuel/Alcohol Triple Blends in a Diesel Engine. Catalysts 2019, 9, 40. [CrossRef]

4. Chum, H.L.; Overend, R.P. Biomass and bioenergy in the United States. Adv. Sol. Energy 2003, 15, 83-148.

5. Akia, M.; Yazdani, F.; Motaee, E.; Han, D.; Arandiyan, H. A review on conversion of biomass to biofuel by nanocatalysts. Biofuel Res. J. 2014, 1, 16-25. [CrossRef]

6. Huber, G.W.; Corma, A. Synergien zwischen Bio-und Ölraffinerien bei der Herstellung von Biomassetreibstoffen. Angew. Chem. 2007, 119, 7320-7338. [CrossRef]

7. Corma, A.; Iborra, S.; Velty, A. Chemical routes for the transformation of biomass into chemicals. Chem. Rev. 2007, 107, 2411-2502. [CrossRef] [PubMed]

8. Pagliaro, M.; Ciriminna, R.; Kimura, H.; Rossi, M.; Della Pina, C. From Glycerol to Value-Added Products. Angew. Chem. Int. Ed. 2007, 46, 4434-4440. [CrossRef]

9. Sheldon, R.A. Green and sustainable manufacture of chemicals from biomass: State of the art. Green Chem. 2014, 16, 950-963. [CrossRef]

10. Cornejo, A.; Barrio, I.; Campoy, M.; Lázaro, J.; Navarrete, B. Oxygenated fuel additives from glycerol valorization. Main production pathways and effects on fuel properties and engine performance: A critical review. Renew. Sustain. Energy Rev. 2017, 79, 1400-1413. [CrossRef]

11. Ragauskas, A.J.; Williams, C.K.; Davison, B.H.; Britovsek, G.; Cairney, J.; Eckert, C.A.; Frederick, W.J.; Hallett, J.P.; Leak, D.J.; Liotta, C.L. The path forward for biofuels and biomaterials. Science 2006, 311, 484-489. [CrossRef]

12. Mohan, S.V.; Nikhil, G.; Chiranjeevi, P.; Reddy, C.N.; Rohit, M.; Kumar, A.N.; Sarkar, O. Waste biorefinery models towards sustainable circular bioeconomy: Critical review and future perspectives. Bioresour. Technol. 2016, 215, 2-12. [CrossRef]

13. Monthly Biodiesel Production Report. Available online: https://www.eia.gov/biofuels/biodiesel/production/ (accessed on 17 June 2019).

14. REN21. Renewable Energy Policy Network for the 21st Century. Renewables 2018 Global Status Report. Available online: http://www.ren21.net/wp-content/uploads/2018/06/17-8652_GSR2018_FullReport_web_ final_.pdf (accessed on 17 June 2019). 
15. Ridjan, I.; Mathiesen, B.V.; Connolly, D.; Duić, N. The feasibility of synthetic fuels in renewable energy systems. Energy 2013, 57, 76-84. [CrossRef]

16. Kumar, A.; Sharma, S. Potential non-edible oil resources as biodiesel feedstock: An Indian perspective. Renew. Sustain. Energy Rev. 2011, 15, 1791-1800. [CrossRef]

17. Knothe, G.; Razon, L.F. Biodiesel fuels. Prog. Energy Combust. Sci. 2017, 58, 36-59. [CrossRef]

18. Borges, M.E.; Díaz, L. Recent developments on heterogeneous catalysts for biodiesel production by oil esterification and transesterification reactions: A review. Renew. Sustain. Energy Rev. 2012, 16, 2839-2849. [CrossRef]

19. Avhad, M.; Marchetti, J. A review on recent advancement in catalytic materials for biodiesel production. Renew. Sustain. Energy Rev. 2015, 50, 696-718. [CrossRef]

20. Ramachandran, K.; Suganya, T.; Gandhi, N.N.; Renganathan, S. Recent developments for biodiesel production by ultrasonic assist transesterification using different heterogeneous catalyst: A review. Renew. Sustain. Energy Rev. 2013, 22, 410-418. [CrossRef]

21. Monteiro, M.R.; Kugelmeier, C.L.; Pinheiro, R.S.; Batalha, M.O.; da Silva César, A. Glycerol from biodiesel production: Technological paths for sustainability. Renew. Sustain. Energy Rev. 2018, 88, 109-122. [CrossRef]

22. Ayoub, M.; Abdullah, A.Z. Critical review on the current scenario and significance of crude glycerol resulting from biodiesel industry towards more sustainable renewable energy industry. Renew. Sustain. Energy Rev. 2012, 16, 2671-2686. [CrossRef]

23. Comelli, R.A. Glycerol, the co-product of biodiesel: One key for the future bio-refinery. In Biodiesel-Quality, Emissions and By-Products; IntechOpen: London, UK, 2011.

24. Luo, X.; Ge, X.; Cui, S.; Li, Y. Value-added processing of crude glycerol into chemicals and polymers. Bioresour. Technol. 2016, 215, 144-154. [CrossRef]

25. Len, C.; Delbecq, F.; Corpas, C.C.; Ramos, E.R. Continuous flow conversion of glycerol into chemicals: An overview. Synthesis 2018, 50, 723-741. [CrossRef]

26. Rahmat, N.; Abdullah, A.Z.; Mohamed, A.R. Recent progress on innovative and potential technologies for glycerol transformation into fuel additives: A critical review. Renew. Sustain. Energy Rev. 2010, 14, 987-1000. [CrossRef]

27. Bagheri, S.; Julkapli, N.M.; Yehye, W.A. Catalytic conversion of biodiesel derived raw glycerol to value added products. Renew. Sustain. Energy Rev. 2015, 41, 113-127. [CrossRef]

28. Nanda, M.R.; Zhang, Y.; Yuan, Z.; Qin, W.; Ghaziaskar, H.S.; Xu, C.C. Catalytic conversion of glycerol for sustainable production of solketal as a fuel additive: A review. Renew. Sustain. Energy Rev. 2016, 56, 1022-1031. [CrossRef]

29. Bozkurt, Ö.D.; Tunc, F.M.; Bağlar, N.; Celebi, S.; Günbaş, İ.D.; Uzun, A. Alternative fuel additives from glycerol by etherification with isobutene: Structure-performance relationships in solid catalysts. Fuel Process. Technol. 2015, 138, 780-804. [CrossRef]

30. Izquierdo, J.; Montiel, M.; Palés, I.; Outón, P.; Galán, M.; Jutglar, L.; Villarrubia, M.; Izquierdo, M.; Hermo, M.; Ariza, X. Fuel additives from glycerol etherification with light olefins: State of the art. Renew. Sustain. Energy Rev. 2012, 16, 6717-6724. [CrossRef]

31. Yee, K.F.; Mohamed, A.R.; Tan, S.H. A review on the evolution of ethyl tert-Butyl ether (ETBE) and its future prospects. Renew. Sustain. Energy Rev. 2013, 22, 604-620. [CrossRef]

32. Garcia, E.; Laca, M.; Pérez, E.; Garrido, A.; Peinado, J. New class of acetal derived from glycerin as a biodiesel fuel component. Energy Fuels 2008, 22, 4274-4280. [CrossRef]

33. Oprescu, E.-E.; Stepan, E.; Dragomir, R.E.; Radu, A.; Rosca, P. Synthesis and testing of glycerol ketals as components for diesel fuel. Fuel Process. Technol. 2013, 110, 214-217. [CrossRef]

34. Zare, A.; Nabi, M.N.; Bodisco, T.A.; Hossain, F.M.; Rahman, M.M.; Ristovski, Z.D.; Brown, R.J. The effect of triacetin as a fuel additive to waste cooking biodiesel on engine performance and exhaust emissions. Fuel 2016, 182, 640-649. [CrossRef]

35. Alptekin, E. Emission, injection and combustion characteristics of biodiesel and oxygenated fuel blends in a common rail diesel engine. Energy 2017, 119, 44-52. [CrossRef]

36. Jaecker-Voirol, A.; Durand, I.; Hillion, G.; Delfort, B.; Montagne, X. Glycerin for new biodiesel formulation. Oil Gas Sci. Technol. Rev. l'IFP 2008, 63, 395-404. [CrossRef]

37. Behr, A.; Obendorf, L. Development of a Process for the Acid-Catalyzed Etherification of Glycerine and Isobutene Forming Glycerine Tertiary Butyl Ethers. Eng. Life Sci. 2002, 2, 185-189. [CrossRef] 
38. Karinen, R.; Krause, A. New biocomponents from glycerol. Appl. Catal. A Gen. 2006, 306, 128-133. [CrossRef]

39. Klepáčová, K.; Mravec, D.; Bajus, M. tert-Butylation of glycerol catalysed by ion-exchange resins. Appl. Catal. A Gen. 2005, 294, 141-147. [CrossRef]

40. Klepáčová, K.; Mravec, D.; Kaszonyi, A.; Bajus, M. Etherification of glycerol and ethylene glycol by isoButylene. Appl. Catal. A Gen. 2007, 328,1-13. [CrossRef]

41. Lee, H.J.; Seung, D.; Jung, K.S.; Kim, H.; Filimonov, I.N. Etherification of glycerol by isoButylene: Tuning the product composition. Appl. Catal. A Gen. 2010, 390, 235-244. [CrossRef]

42. Lee, H.J.; Seung, D.; Filimonov, I.N.; Kim, H. Etherification of glycerol by isoButylene. Effects of the density of acidic sites in ion-exchange resin on the distribution of products. Korean J. Chem. Eng. 2011, 28, 756-762. [CrossRef]

43. Bozkurt, Ö.D.; Bağlar, N.; Çelebi, S.; Uzun, A. Assessment of acid strength in sodium-exchanged resin catalysts: Consequences on glycerol etherification with isobutene in batch and flow reactors. Mol. Catal. 2019, 466, 1-12. [CrossRef]

44. Melero, J.; Vicente, G.; Morales, G.; Paniagua, M.; Moreno, J.; Roldán, R.; Ezquerro, A.; Pérez, C. Acid-catalyzed etherification of bio-glycerol and isoButylene over sulfonic mesostructured silicas. Appl. Catal. A Gen. 2008, 346, 44-51. [CrossRef]

45. Zhao, W.; Yi, C.; Yang, B.; Hu, J.; Huang, X. Etherification of glycerol and isoButylene catalyzed over rare earth modified H $\beta$-zeolite. Fuel Process. Technol. 2013, 112, 70-75. [CrossRef]

46. Xiao, L.; Mao, J.; Zhou, J.; Guo, X.; Zhang, S. Enhanced performance of HY zeolites by acid wash for glycerol etherification with isobutene. Appl. Catal. A Gen. 2011, 393, 88-95. [CrossRef]

47. González, M.D.; Salagre, P.; Taboada, E.; Llorca, J.; Cesteros, Y. Microwave-assisted synthesis of sulfonic acid-functionalized microporous materials for the catalytic etherification of glycerol with isobutene. Green Chem. 2013, 15, 2230-2239. [CrossRef]

48. González, M.D.; Cesteros, Y.; Llorca, J.; Salagre, P. Boosted selectivity toward high glycerol tertiary Butyl ethers by microwave-assisted sulfonic acid-functionalization of SBA-15 and beta zeolite. J. Catal. 2012, 290, 202-209. [CrossRef]

49. González, M.D.; Salagre, P.; Mokaya, R.; Cesteros, Y. Tuning the acidic and textural properties of ordered mesoporous silicas for their application as catalysts in the etherification of glycerol with isobutene. Catal. Today 2014, 227, 171-178. [CrossRef]

50. González, M.D.; Salagre, P.; Taboada, E.; Llorca, J.; Molins, E.; Cesteros, Y. Sulfonic acid-functionalized aerogels as high resistant to deactivation catalysts for the etherification of glycerol with isobutene. Appl. Catal. B Environ. 2013, 136, 287-293. [CrossRef]

51. Frusteri, F.; Cannilla, C.; Bonura, G.; Spadaro, L.; Mezzapica, A.; Beatrice, C.; Di Blasio, G.; Guido, C. Glycerol ethers production and engine performance with diesel/ethers blend. Top. Catal. 2013, 56, 378-383. [CrossRef]

52. Beatrice, C.; Di Blasio, G.; Lazzaro, M.; Cannilla, C.; Bonura, G.; Frusteri, F.; Asdrubali, F.; Baldinelli, G.; Presciutti, A.; Fantozzi, F. Technologies for energetic exploitation of biodiesel chain derived glycerol: Oxy-fuels production by catalytic conversion. Appl. Energy 2013, 102, 63-71. [CrossRef]

53. Frusteri, F.; Frusteri, L.; Cannilla, C.; Bonura, G. Catalytic etherification of glycerol to produce biofuels over novel spherical silica supported Hyflon®catalysts. Bioresour. Technol. 2012, 118, 350-358. [CrossRef] [PubMed]

54. Zhao, W.; Yang, B.; Yi, C.; Lei, Z.; Xu, J. Etherification of glycerol with isoButylene to produce oxygenate additive using sulfonated peanut shell catalyst. Ind. Eng. Chem. Res. 2010, 49, 12399-12404. [CrossRef]

55. Zhou, J.; Wang, Y.; Guo, X.; Mao, J.; Zhang, S. Etherification of glycerol with isobutene on sulfonated graphene: Reaction and separation. Green Chem. 2014, 16, 4669-4679. [CrossRef]

56. Voicu, V.; Bombos, D.; Bolocan, I.; Jang, C.R.; Ciuparu, D. The Influence of the Character of Emulsifiers on the Performance of $\mathrm{H}$ (4) SiW (12) O (40 center dot) $30 \mathrm{H}$ (2) O Heteropolyacid Catalyst in Glycerol Etherification with Isobutene. Rev. Chim. 2012, 63, 200-204.

57. Liu, J.; Yuan, Y.; Pan, Y.; Huang, Z.; Yang, B. Liquid-liquid equilibrium for systems of glycerol and glycerol tert-Butyl ethers. Fluid Phase Equilibria 2014, 365, 50-57. [CrossRef]

58. Liu, J.; Yang, B.; Yi, C. Kinetic study of glycerol etherification with isobutene. Ind. Eng. Chem. Res. 2013, 52, 3742-3751. [CrossRef]

59. Di Serio, M.; Cozzolino, M.; Giordano, M.; Tesser, R.; Patrono, P.; Santacesaria, E. From homogeneous to heterogeneous catalysts in biodiesel production. Ind. Eng. Chem. Res. 2007, 46, 6379-6384. [CrossRef] 
60. Liu, J.; Daoutidis, P.; Yang, B. Process design and optimization for etherification of glycerol with isobutene. Chem. Eng. Sci. 2016, 144, 326-335. [CrossRef]

61. Turan, A.; Hrivnák, M.; Klepáčová, K.; Kaszonyi, A.; Mravec, D. Catalytic etherification of bioglycerol with C4 fraction. Appl. Catal. A Gen. 2013, 468, 313-321. [CrossRef]

62. Kiatkittipong, W.; Intaracharoen, P.; Laosiripojana, N.; Chaisuk, C.; Praserthdam, P.; Assabumrungrat, S. Glycerol ethers synthesis from glycerol etherification with tert-Butyl alcohol in reactive distillation. Comput. Chem. Eng. 2011, 35, 2034-2043. [CrossRef]

63. González, M.D.; Salagre, P.; Linares, M.; García, R.; Serrano, D.; Cesteros, Y. Effect of hierarchical porosity and fluorination on the catalytic properties of zeolite beta for glycerol etherification. Appl. Catal. A Gen. 2014, 473, 75-82. [CrossRef]

64. Klepáčová, K.; Mravec, D.; Bajus, M. Etherification of glycerol with tert-Butyl alcohol catalysed by ion-exchange resins. Chem. Pap. 2006, 60, 224-230. [CrossRef]

65. Chang, J.-S.; Zhang, Y.-C.; Chen, C.-C.; Ling, T.-R.; Chiou, Y.-J.; Wang, G.-B.; Chang, K.-T.; Chou, T.-C. One-step synthesis of gasoline octane booster and diesel fuel from glycerol and tert-Butyl alcohol. Ind. Eng. Chem. Res. 2014, 53, 5398-5405. [CrossRef]

66. Frusteri, F.; Arena, F.; Bonura, G.; Cannilla, C.; Spadaro, L.; Di Blasi, O. Catalytic etherification of glycerol by tert-Butyl alcohol to produce oxygenated additives for diesel fuel. Appl. Catal. A Gen. 2009, 367, 77-83. [CrossRef]

67. Cannilla, C.; Bonura, G.; Frusteri, L.; Frusteri, F. Glycerol Etherification with TBA: High Yield to Poly-Ethers Using a Membrane Assisted Batch Reactor. Environ. Sci. Technol. 2014, 48, 6019-6026. [CrossRef] [PubMed]

68. Cannilla, C.; Bonura, G.; Frusteri, L.; Frusteri, F. Catalytic production of oxygenated additives by glycerol etherification. Open Chem. 2014, 12, 1248-1254. [CrossRef]

69. Gonçalves, M.; Souza, V.C.; Galhardo, T.S.; Mantovani, M.; Figueiredo, F.v.C.; Mandelli, D.; Carvalho, W.A. Glycerol conversion catalyzed by carbons prepared from agroindustrial wastes. Ind. Eng. Chem. Res. 2013, 52, 2832-2839. [CrossRef]

70. Galhardo, T.S.; Simone, N.; Gonçalves, M.; Figueiredo, F.C.; Mandelli, D.; Carvalho, W.A. Preparation of sulfonated carbons from rice husk and their application in catalytic conversion of glycerol. ACS Sustain. Chem. Eng. 2013, 1, 1381-1389. [CrossRef]

71. Gonçalves, M.; Soler, F.C.; Isoda, N.; Carvalho, W.A.; Mandelli, D.; Sepúlveda, J. Glycerol conversion into value-added products in presence of a green recyclable catalyst: Acid black carbon obtained from coffee ground wastes. J. Taiwan Inst. Chem. Eng. 2016, 60, 294-301. [CrossRef]

72. Gonçalves, M.; Mantovani, M.; Carvalho, W.A.; Rodrigues, R.; Mandelli, D.; Albero, J.S. Biodiesel wastes: An abundant and promising source for the preparation of acidic catalysts for utilization in etherification reaction. Chem. Eng. J. 2014, 256, 468-474. [CrossRef]

73. Pico, M.P.; Rosas, J.M.; Rodríguez, S.; Santos, A.; Romero, A. Glycerol etherification over acid ion exchange resins: Effect of catalyst concentration and reusability. J. Chem. Technol. Biotechnol. 2013, 88, 2027-2038. [CrossRef]

74. Pico, M.P.; Romero, A.; Rodríguez, S.; Santos, A. Etherification of glycerol by tert-Butyl alcohol: Kinetic model. Ind. Eng. Chem. Res. 2012, 51, 9500-9509. [CrossRef]

75. Magar, S.; Kamble, S.; Mohanraj, G.T.; Jana, S.K.; Rode, C. Solid-Acid-Catalyzed Etherification of Glycerol to Potential Fuel Additives. Energy Fuels 2017, 31, 12272-12277. [CrossRef]

76. Celdeira, P.A.; Goncalves, M.; Figueiredo, F.C.; Dal Bosco, S.M.; Mandelli, D.; Carvalho, W.A. Sulfonated niobia and pillared clay as catalysts in etherification reaction of glycerol. Appl. Catal. A Gen. 2014, 478, 98-106. [CrossRef]

77. Srinivas, M.; Raveendra, G.; Parameswaram, G.; Prasad, P.S.; Lingaiah, N. Cesium exchanged tungstophosphoric acid supported on tin oxide: An efficient solid acid catalyst for etherification of glycerol with tert-butanol to synthesize biofuel additives. J. Mol. Catal. A Chem. 2016, 413, 7-14. [CrossRef]

78. González, M.D.; Cesteros, Y.; Salagre, P. Establishing the role of Brønsted acidity and porosity for the catalytic etherification of glycerol with tert-butanol by modifying zeolites. Appl. Catal. A Gen. 2013, 450, 178-188. [CrossRef]

79. Simone, N.; Carvalho, W.A.; Mandelli, D.; Ryoo, R. Nanostructured MFI-type zeolites as catalysts in glycerol etherification with tert-Butyl alcohol. J. Mol. Catal. A Chem. 2016, 422, 115-121. [CrossRef] 
80. Estevez, R.; Iglesias, I.; Luna, D.; Bautista, F.M. Sulfonic Acid Functionalization of Different Zeolites and Their Use as Catalysts in the Microwave-Assisted Etherification of Glycerol with tert-Butyl Alcohol. Molecules 2017, 22, 2206. [CrossRef]

81. Miranda, C.; Urresta, J.; Cruchade, H.; Tran, A.; Benghalem, M.; Astafan, A.; Gaudin, P.; Daou, T.; Ramírez, A.; Pouilloux, Y. Exploring the impact of zeolite porous voids in liquid phase reactions: The case of glycerol etherification by tert-Butyl alcohol. J. Catal. 2018, 365, 249-260. [CrossRef]

82. Veiga, P.M.; Gomes, A.C.; Veloso, C.O.; Henriques, C.A. Acid zeolites for glycerol etherification with ethyl alcohol: Catalytic activity and catalyst properties. Appl. Catal. A Gen. 2017, 548, 2-15. [CrossRef]

83. Estevez, R.; López, M.; Jiménez-Sanchidrián, C.; Luna, D.; Romero-Salguero, F.; Bautista, F. Etherification of glycerol with tert-Butyl alcohol over sulfonated hybrid silicas. Appl. Catal. A Gen. 2016, 526, 155-163. [CrossRef]

84. Estevez, R.; Lopez-Pedrajas, S.; Luna, D.; Bautista, F. Microwave-assisted etherification of glycerol with tert-Butyl alcohol over amorphous organosilica-aluminum phosphates. Appl. Catal. B Environ. 2017, 213, 42-52. [CrossRef]

85. Ozbay, N.; Oktar, N.; Dogu, G.; Dogu, T. Effects of sorption enhancement and isobutene formation on etherification of glycerol with tert-Butyl alcohol in a flow reactor. Ind. Eng. Chem. Res. 2011, 51, 8788-8795. [CrossRef]

86. Ozbay, N.; Oktar, N.; Dogu, G.; Dogu, T. Activity comparison of different solid acid catalysts in etherification of glycerol with tert-Butyl alcohol in flow and batch reactors. Top. Catal. 2013, 56, 1790-1803. [CrossRef]

87. Viswanadham, N.; Saxena, S.K. Etherification of glycerol for improved production of oxygenates. Fuel 2013, 103, 980-986. [CrossRef]

88. Vlad, E.; Bildea, C.S.; Bozga, G. Design and control of glycerol-tert-Butyl alcohol etherification process. Sci. World J. 2012, 2012, 180617. [CrossRef] [PubMed]

89. Vlad, E.; Bildea, C.S. Reactive Distillation-a Viable Solution for Etherification of Glycerol with tert-Butyl Alcohol. Chem. Eng. 2012, 29. [CrossRef]

90. Simasatitkul, L.; Kaewwisetkul, P.; Arpornwichanop, A. Techno-economic assessment of extractive distillation for tert-Butyl alcohol recovery in fuel additive production. Chem. Eng. Process. Process Intensif. 2017, 122, 161-171. [CrossRef]

91. Singh, J.; Kumar, J.; Negi, M.; Bangwal, D.; Kaul, S.; Garg, M. Kinetics and modeling study on etherification of glycerol using isoButylene by in situ production from tert-Butyl alcohol. Ind. Eng. Chem. Res. 2015, 54, 5213-5219. [CrossRef]

92. Luque, R.; Budarin, V.; Clark, J.H.; Macquarrie, D.J. Glycerol transformations on polysaccharide derived mesoporous materials. Appl. Catal. B Environ. 2008, 82, 157-162. [CrossRef]

93. Noureddini, H.; Dailey, W.R.; Hunt, B.A. Production of ethers of glycerol from crude glycerol-the by-product of biodlesel production. Pap. Biomater. 1998, 18.

94. Noureddini, H. Process for producing biodiesel fuel with reduced viscosity and a cloud point below thirty-two (32) degrees Fahrenheit. U.S. Patent 6,015,440, 18 January 2000.

95. Melero, J.A.; Vicente, G.; Morales, G.; Paniagua, M.; Bustamante, J. Oxygenated compounds derived from glycerol for biodiesel formulation: Influence on EN 14214 quality parameters. Fuel 2010, 89, 2011-2018. [CrossRef]

96. Beatrice, C.; Di Blasio, G.; Lazzaro, M.; Mancaruso, E.; Marialto, R.; Sequino, L.; Vaglieco, B.M. Investigation of the combustion in both metal and optical diesel engines using high-glycerol ethers/diesel blends. Int. J. Engine Res. 2015, 16, 38-51. [CrossRef]

97. Samoilov, V.O.; Ramazanov, D.N.; Nekhaev, A.I.; Maximov, A.L.; Bagdasarov, L.N. Heterogeneous catalytic conversion of glycerol to oxygenated fuel additives. Fuel 2016, 172, 310-319. [CrossRef]

(C) 2019 by the authors. Licensee MDPI, Basel, Switzerland. This article is an open access article distributed under the terms and conditions of the Creative Commons Attribution (CC BY) license (http://creativecommons.org/licenses/by/4.0/). 